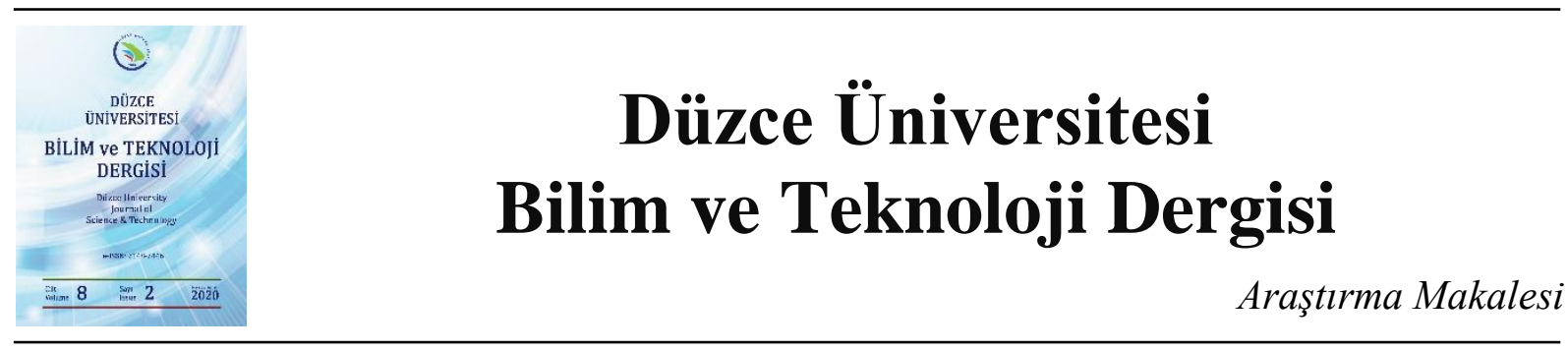

\section{İlyasbey Camisi’nin Yapısal Davranışının Çevresel Titreşim Testi ve Sonlu Eleman Yöntemleriyle İncelenmesi}

\author{
Temel TÜRKER ${ }^{\mathrm{a}, *}$, (D) Yusuf YANIK ${ }^{\mathrm{b}}$ \\ ${ }^{a}$ Inşaat Mühendisliği Bölümü, Mühendislik Fakültesi, Karadeniz Teknik Üniversitesi, Trabzon, TÜRKIYYE \\ ${ }^{b}$ Inşaat Mühendisliği Bölümü, Mühendislik Fakültesi, Karadeniz Teknik Üniversitesi, Trabzon, TÜRKIYY \\ * Sorumlu yazartn e-posta adresi: temelturker@ktu.edu.tr
}

DOI : 10.29130/dubited.627927

\begin{abstract}
ÖZET
Kültürel mirasımızın önemli bir parçası olan camiler zaman içinde doğal afetler veya çeşitli sebepler neticesinde hasarlara maruz kalmaktadır. Bu nedenle camiler, zaman zaman restore edilmekte ve korunmaktadır. Tarihi yapıları korumak için mevcut yapısal davranışlarının çok iyi bilinmesi ve değerlendirilmesi gerekmektedir. Yapısal davranışları belirlemek için camilerin dinamik karakteristikleri belirlenmelidir. Bu çalışmada, İlyasbey Camisi'nin çevresel titreşim testi, üç boyutlu Sonlu eleman modeli oluşturma, model kalibrasyonu ve sabit yük, rüzgâr yükü ve deprem yükü etkileri altında analizleri incelenmiştir. Dinamik ölçümleri çevresel titreşimler altında Çevresel Titreşim Testi Yöntemiyle, analitik ölçümleri ise Sonlu Eleman Yöntemiyle gerçekleştirilmiştir. İlyasbey Camisi'nin başlangıç Sonlu Eleman modeli, cami üzerinde gerçekleştirilen çevresel titreşim testi sonuçlarına göre kalibre edilmiş ve statik ve deprem yükleri etkisindeki analizleri değerlendirilmiştir. İlyasbey Camisi için sabit yük, rüzgâr yükü ve deprem yükü etkileri altında gerçekleştirilen analizlerden, minarede oluşan yerdeğiştirmeler ile çekme, basınç ve kayma gerilmelerinin dağılımları elde edilmiş̧ir.
\end{abstract}

Anahtar Kelimeler: Ilyasbey Cami, Model Kalibrasyon, Operasyonal Modal Analiz, Titreşim Testi

\section{Ambient Vibration Test and Structural Analysis of İlyasbey Mosque}

\begin{abstract}
Mosques, which are an important part of our cultural heritage, are subject to damage over time due to natural disasters or various reasons. For this reason, mosques are restored and preserved from time to time. In order to preserve historical buildings, the existing structural behaviors need to be well known and evaluated. To determine the structural behavior, the dynamic characteristics of the mosques should be determined. In this study, Ilyasbey Mosque's ambient vibration test, three-dimensional finite element modeling, model calibration and analysis under the effect of dead load, wind load and earthquake load were examined. Dynamic measurements were carried out under environmental vibrations by Ambient Vibration Test Method and analytical measurements by Finite Element Method. The initial finite element model of the Ilyasbey Mosque was calibrated according to the results of the environmental vibration test performed on the mosque and its analyzes under static and earthquake loads were evaluated. The displacement of the minaret and the distributions of tensile, pressure and shear stresses were obtained from the analysis carried out under the effect of dead load, wind load and earthquake load for the Ilyasbey Mosque.
\end{abstract}

Keywords: Ilyasbey Mosque, Modal Calibration, Operational Modal Analysis, Vibration Test 


\section{GIRIS}

Deprem kuşağında bulunan ülkemizde geçmişin birikimlerini geleceğe aktaran oldukça fazla tarihi yapı bulunmaktadır. Bunların başında hiç şüphesiz camiler gelmektedir. Camiler depremler, zamana bağlı hasarlar, zemin oturmaları, yangınlar, savaşlar vb. gibi nedenlerle hasar görebilmekte hatta hizmet dışı kalabilmektedir. Değişik sebeplerle oluşan hasarların belirlenmesi ve giderilmesi gerekmektedir. Tarihi yapıda oluşan hasarların onarımı ve korunması için öncelikle yapının dinamik davranışlarının doğru bir şekilde belirlenmesi gerekmektedir. Bunun için hem deneysel hem de analitik birtakım çalışmalar yapılmaktadır. Bu amaçla kullanılan Sonlu Eleman Yöntemi analitik bir çözüm yöntemidir. Sonlu Eleman Yönteminin kullanılması yapısal davranışın belirlenmesine yardımcı olmakta fakat tek başına yeterli olmamaktadır. Bu nedenle Sonlu Eleman Yöntemiyle belirlenen dinamik davranışın deneysel yöntemlerle doğrulanması gerekmektedir. Doğrulanan dinamik karakteristiklerle tarihi yapının mevcut durumu daha doğru bir şekilde belirlenebilmektedir.

Literatürde tarihi yapılar üzerine birçok deneysel ve analitik çalışmalar yapılmıştır. Teorik çalışmalarda genellikle statik ve dinamik yükler etkisindeki davranışlar incelenmiştir. Deneysel olarak Operasyonal Modal Analiz Yöntemi ve teorik olarak Sonlu Eleman Yöntemi yaygın bir biçimde kullanılmakta ve tarihi camilerin deneysel ve teorik dinamik karakteristikleri belirlenmektedir. Yapıların Sonlu Eleman modellerinin Operasyonal Modal Analiz verileri kullanılarak kalibre edilmesi, başka bir deyişle yapıların mevcut davranışlarını en iyi şekilde yansıtabilecek olan Sonlu Eleman modellerini elde edebilmek için Operasyonal Modal Analiz Yöntemi oldukça etkin sonuç verdiği görülmektedir. Bayraktar vd., Trabzon İlinin Akçaabat İlçesinde bulunan Şinik Köprüsü'nü tarihi köprüler üzerinde yapılan Sonlu Eleman model iyileştirmesinin deprem davranışına etkisini araştırmak amaciyla ANSYS programıyla üç boyutlu modal analiz sonucunda doğal frekans ve mod şekillerini belirlemişlerdir. Operasyonal Modal Analiz Yöntemiyle köprünün dinamik karakteristikleri belirlenmiştir. Deneysel ve teorik karakteristikler birbirleriyle karşılaştırılmış ve köprünün mevcut durumunu yansıtan Sonlu Eleman modeli hazırlanmıştır [1]. Birinci, taş kemer köprülerin dinamik karakteristiklerinin deneysel ve teorik olarak belirlenmesini ve Operasyonal Modal Analiz Yöntemi yardımıyla seçilen Şenyuva ve Osmanlı köprülerinin Sonlu Eleman modelleri iyileştirilmeye çalışmıştır. Bu köprüler ANSYS programında oluşturularak teorik analizleri gerçekleştirilmiş ve köprülerin dinamik karakteristikleri Operasyonal Modal Analiz Yöntemiyle belirlenmiştir. Elde edilen teorik ve deneysel analiz sonuçları birbirleriyle karşılaştırılmış ve sonuçlar arasındaki farkları en aza indirecek şekilde Sonlu Eleman model iyileştirmesi gerçekleştirilmiştir [2]. Türker, yapmış olduğu çalışmada çevresel titreşimler altında deneysel olarak ölçülen dinamik karakteristikleri dikkate alarak yapıların hasar durumlarının tespiti ve değerlendirilmesine olanak sağlayan bir yaklaşım üzerinde çalışmıştır. Temel mühendislik yapılarını temsil eden laboratuvar modelleri üzerinde gerçekleştirilen incelemelerle bu yaklaşımın yapıların hasar durumlarının tespiti ve değerlendirilmesinde oldukça etkili olduğu ortaya çıkmıştır [3]. Oliveira vd., farklı boyutlardaki eski minarelere bir dizi yerinde ortam titreşim testi uygulanmış ve aynı yapıların sayısal modellenmesiyle elde edilen frekanslar değerleri karşılaştırılmıştır [4]. Baştürk, Bursa'da yer alan yedi adet tarihi minarede yapmış olduğu çalışma kapsamında minarelerin geometrik özellikleri, malzeme özellikleri ve yapım teknikleri hakkında bilgiler vermiş ve dinamik karakteristikler Çevresel Titreşim Testleriyle değerlendirmiştir. Minarelerin Sonlu Eleman modelleri oluşturduktan sonra malzeme özelliklerinde ve mesnetlenme koşullarında güncelleme yapılarak Sonlu Eleman analizlerinden alınan sonuçlarla deneysel ölçüm sonuçları kıyaslanmıştır [5]. Ercan ve Nuhoğlu, çalışmalarında üç açıklıklı İzmir Çeşme'de birinci derece deprem bölgesinde bulunan tarihi kemer köprünün statik ve dinamik yapısal özelliklerini şiddetli bir depremde göstereceği davranışı araştırmışlardır. Yapının dinamik karakteristikleri Operasyonal Modal Analiz Yöntemiyle elde edilmiştir. Elde edilen deneysel ve teorik analiz sonuçları değerlendirilip iyileştirilen model üzerinde davranış spektrumu analizi yapılarak köprünün deprem performans1 değerlendirilmiş̧tir [6]. Türker vd., çalışmalarında oluşturdukları 1/10 ölçekli taş kemer köprü modelin dinamik karakteristiklerini Çevresel Titreşim Testi Yöntemi aracılığıyla elde etmiş ve SAP2000 programını kullanarak modelin modal analizini yapmışlardır. Deneysel olarak elde edilen sonuçlarla modal analiz sonuçları kıyaslayarak farklılıkları değerlendirmişlerdir [7]. Ural ve Fırat, Aksaray şehri 12 Mart 2013'te şiddetli bir rüzgârda hasar gören üç minarede yapısal incelemeler ve hasarın nedeni 
ayrıntılı olarak ele almışlardır. Kendi ağırlığı ve rüzgâr yüklerine göre çökmüş bir minarede doğrusal malzeme özellikleri altında ilk analizler gerçekleştirilirken, ikinci analiz doğrusal olmayan malzeme davranış1 altında gerçekleştirmişlerdir [8]. Preciado, tarihi duvar kulelerinin sismik performanslarını değerlendirmiştir [9]. Kömür vd., çalışmalarında tek katlı-tek açıklıklı ve üç katlı-tek açıklıklı olmak üzere laboratuvarda hazırlanmış küçük ölçekli çelik çerçevelerin Operasyonal Modal Analiz Yöntemi yardımılla dinamik karakteristikleri belirlenmiş ve sistemin SAP2000 programında Sonlu Eleman modelleri oluşturulduktan sonra dinamik karakteristikler nümerik olarak belirlenmiştir. Daha sonra Operasyonal Modal Analiz Yöntemi ile çerçeve sistemlerin dinamik karakteristikleri belirlenip bu iki analizden elde dilen sonuçlar kıyaslanmıştır [10]. Kocatürk ve Erdoğan (2016), tarihi duvar minarelerinin doğrusal ve doğrusal olmayan deprem davranışlarını araştırmışlardır [11]. Livaoğlu vd., geometrik özelliklerin etkisini Bursa'daki yedi tarihi duvar minaresinin dinamik davranışı için incelenmiştir. Bununla birlikte, tarihi duvar minarelerinin modal parametrelerinin tanımlanması amacıyla Çevresel Titreşim Testi yapılmışıır. Tarihi minarelerin yapısal davranışları matematiksel modellerle de temsil edildiğinden, Sonlu Eleman yazılımı Abaqus Cae kullanılarak üç boyutlu (katı) modelleri oluşturulmuştur. Sayısal sonuçlardan ve deneysel araştırmalardan elde edilen doğal frekansları eşleştirmek için model güncellemesi yapılmıştır. Elde edilen sonuçlara göre, geometrik özelliklerin minarelerin dinamik davranışları üzerindeki etkisi değerlendirilmiştir [12]. Hacıefendioğlu ve Maraş, sayısal ve deneysel analizler yaparak bir duvar tipi tarihi minarenin modal parametrelerini araştırmışlardır. Deneysel çalışma için tarihi minarenin modal parametrelerinin elde edilmesinde Operasyonal Modal Analiz tekniğini Samsun'da bulunan Büyük Cami üzerinde gerçekleştirmiş, doğal frekansları ve mod şekillerini deneysel olarak tanımlamak için Frekans Alanı Ayrıştırma (FDD) yöntemini kullanmışlardır. Ayrıca fotogrametri yöntemini minareyi belgelemek ve Sonlu Eleman modeli oluşturmak için kullanılmışlardır. Tarihi minarenin 3B SE modellemesini gerçekleştirmek ve minarenin doğal frekanslarını ve mod şekillerini analitik olarak belirlemek için ANSYS yazılımı kullanılmıştır. Ayrıca, minarenin SE modeli, yapının modal parametrelerinin daha doğru sonuçlar elde etmek için Tepki Yüzey Tabanlı SE model kalibrasyon tekniği kullanılarak yapılan deney sonuçlarına göre kalibre edilmiştir [13]. Çalık vd., 2015 yılında taşınmaz kültür mirası kapsamında restore edilen Trabzon Ortahisar Molla Siyah Cami'nin dinamik özelliklerini restorasyon öncesi ve sonrası Çevresel Titreşim Testi kullanılarak belirlemişlerdir [14]. McDonald, yapmış olduğu çalışmada model güncellemenin, Sonlu Eleman modellerinin kalibre edilmesinin ve fiziksel olarak anlamlı parametrelerin muhafaza edilmesinin önemini kanıtlamıştır. Bunun için köprüde öngörülen sismik davranış üzerinde büyük bir etkiye sahip olduğu sonucunu çıkarmıştır [15]. Çalık vd., ahşap çatılı tarihi yığma camilerin ahşap çatısının yerine betonarme kubbe yapılmasının tarihi taş duvarlı camilerin dinamik özelliklerini nasıl etkilediği üzerinde çalışmışlardır. [16]. Uçak vd., seçilen iki tarihi yapı olan Hamza Paşa Türbesi ve Kavak Meydan Çeşmesi'nin Operasyonal Modal Analiz testi, analitik modal analizi ve başlangıç Sonlu Eleman modelinin kalibrasyonu üzerinde çalışmışlardır [17]. Hejazi vd., İran'ın 11. ve 12. yyda inşa edilen dokuz tarihi tuğla duvar minarenin yapısal ağırlı̆̆ı, sıcaklık, rüzgâr ve deprem altında yapısal davranışı incelenmiştir. Doğrusal olmayan üç boyutlu Sonlu Eleman modeli oluşturulmuş ve merkezi kolon ve döner merdivenlerin yapısal davranış üzerindeki etkisini araştırmak için tam minare ve sadece dış kabuk için analizleri yapılmıştır [18]. Çalık vd., Trabzon'un Akçaabat ilçesinde bulunan Dürbinar Mahallesi Camisi, 2013 yılında Trabzon Vakıflar Bölge Müdürlüğü tarafından restore edilmiş olup eserin restorasyon öncesi dinamik özelliklerini Çevresel Titreşim Testi Yöntemiyle ölçülmüş ve mevcut duruma ait doğal frekanslarını, mod şekillerini ve modal sönüm oranlarını belirlemişlerdir. Restorasyon uygulamasının ardından ölçümler tekrarlanmış ve onarım sonrası durum için dinamik karakteristikleri tekrar elde etmiş ve verileri kıyaslamışlardır [19]. Türker ve Bayraktar, inşaat aşamalarının betonarme binaların modal parametrelerine etkileri üzerinde çalışmışlardır. Bu amaçla, 1/2 ölçekli çerçeveli, tuğla duvarlı ve sıvalı durumlarda üç katlı bir betonarme yapı modeli oluşturularak modal test ölçümleri Operasyonal Modal Analiz Yöntemiyle yapılmıştır [20]. Mirtaheri vd., deneysel ve sayısal yöntemler kullanılarak, tarihi bir minarenin sismik davranışını ve rehabilitasyonunu incelemişlerdir [21]. Bartoli vd., araştırma projesi RISSEM (Anıtsal Yapıların Sismik Riski) "Kültürel mirasın sismik riskinin değerlendirilmesi ve azaltılması için kılavuzlara" göre tarihi duvar kulelerinin sismik değerlendirmesini üç farklı değerlendirme seviyesine dayanan bir analiz metodolojisini tanımlamışlardır. RİSEM projesi, sismik güvenliklerinin değerlendirilmesi için gerekli olan anıtsal yapıların tüm temel yapısal özelliklerini değerlendirmek için yenilikçi ve hızlı metodolojileri (yani, duvarcılık binaları ile en az doğrudan temas olmadan veya 
bunlarla temasa geçmeden) geliştirmeyi ve test etmeyi amaçlamıştır [22]. Çalık vd., pencere açma çalışmalarının Trabzon Fatih Cami'nin statik ve sismik davranışlarına etkisini incelemişlerdir. Caminin Sonlu Eleman modeli, Çevresel Titreşim Testlerinden elde edilen deneysel dinamik özellikler kalibre edilerek doğrulanmış ve incelenmiştir [23]. Yanık vd., yapı elemanlarının malzeme özelliklerini belirlemek amacıyla deneysel ve analitik çalı̧̧malar gerçekleştirerek yapı elemanın malzeme özelliğinin gerçeğe en yakın değerini hesaplamaya çalışmışlardır [24]. Erdil vd., Van Ulu Cami minaresinin Van depreminden sonra önemli derecede hasar görmesi ve çatlakların yaklaşık $10 \mathrm{~cm}$ genişliğinde olmasının nedenini anlamak için, önce altı 3 boyutlu SE modeli oluşturulmuş, deprem davranışları incelenmiş ve Operasyonal Modal Analiz Yöntemiyle de dinamik karakteristikleri belirlemişlerdir [25]. Bayraktar vd., Trabzon ili Vakıf Bölge Müdürlüğü tarafından restore edilen üç tarihi taş minarenin dinamik özelliklerini Çevresel Titreşim Test verileri kullanılarak yapılan restorasyon etkileri incelenmiştir [26].

Bu çalışmada, İlyasbey Camisi'nin Çevresel Titreşim Testleri yapılarak dinamik karakteristikleri deneysel olarak belirlenmiştir. Başlangıç analitik model üzerinde yapılan Sonlu Eleman Yöntemiyle dinamik karakteristikler teorik olarak elde edilmiştir. Elde edilen deneysel ve analitik değerler yardımıyla başlangıç analitik model kalibre edilmiştir. Kalibrasyon işlemiyle deneysel ve teorik frekanslar arasında fark başlangıçtaki duruma göre azaltılabilmiştir. Kalibre edilen analitik modelin mevcut caminin davranışını daha gerçekçi temsil ettiği kabul edilmektedir. Kalibre edilen model üzerinde sabit yük, rüzgâr yükü ve deprem yükü etkileri altında analizleri gerçekleştirilmiş ve yapılan analizlerden minarede meydana gelen yerdeğiştirmelerle birlikte çekme, basınç ve kayma gerilmelerinin dağılımları hesaplanmıştır.

\section{CEVRESEL TITREŞIM TESTI, MODEL KALIBBRASYON SÜRECLERI}

Operasyonal Modal Analiz Yöntemi olarak da bilinen Çevresel Titreşim Yönteminde yapının veya elemanın çevresel etkilerle titreştirilmekte ve bu etkiler çerçevesinde yapının etkilere vermiş olduğu tepkiler ölçülmektedir [27-28]. Bu yöntemde, ölçümü yapılacak yapının dinamik karakteristikleri yapının ya da elemanın belirli noktalarından alınan titreşimlerle değerlendirilmektedir. Bu durumda elemanın dinamik karakteristikleri frekans ve zaman tanım alanında algoritmalara sahip yöntemlerle elde edilmektedir. Bu yöntemlerin matematik tabanları aynıdır sadece veri işleme ve denklem çözme teknikleriyle matris dizilişleri birbirinden farklıdır. Frekans tanım alanındaki yöntem (parametrik olmayan yöntem), her bir noktada ölçülen sinyalin analizine ve bu sinyaller arası korelasyona bağlıdır. $\mathrm{Bu}$ yöntemde gürültü rahatlıkla ayırt edilebilir olup filtreleme işlemi kolayca yapılabilmektedir. Ayrıca bu yöntemde birbirine yakın frekans değerleri daha kolay bir şekilde fark edilebilmektedir [29]. Piklerin Seçilmesi Yöntemi, Frekans Tanım Alanında Ayrıştırma Yöntemi, Geliştirilmiş Frekans Tanım Alanında Ayrıştırma Yöntemi ve Polimaks yöntemleri frekans tanım alanındaki başlıca yöntemlerdir. Zaman tanım alanındaki yöntemde ise her bir noktada sinyalin zaman geçmişine ve korelasyon fonksiyonlarıyla model uydurmaya bağlıdır. Rastgele Azalım Yöntemi, Rekürsif Teknikler, En Büyük Olabilirlik Yöntemleri ve Stokastik Altalan Belirleme yöntemleri zaman ortamındaki başlıca yöntemlerdir [29].

Geliştirilmiş Frekans Tanım Alanında Ayrıştırma (GFTAA) Yöntemi kullanımı kolay olan Frekans Tanım Alanında Ayrıştırma (FTAA) yönteminin genişletilmiş durumudur. Bu yöntemde, spektral yoğunluk fonksiyonundan hesaplanan tekil değer ayrıştırma grafiklerindeki piklerin seçilmesiyle modlar belirlenir. FTAA yöntemi, Hızlı Fourier Dönüşümünden (FFT) tek bir frekans hattının kullanımına dayalı olduğundan, belirlenen doğal frekansın kesinliği FFT’nin çözünürlüğüne dayanmaktadır. FTAA yönteminde yapının sönüm oranları belirlenememesine rağmen GFTAA yönteminde, belirlenen doğal frekansların ve mod şekillerinin kesinliği artırılmakta, sönüm oranları da ayrıca belirlenebilmektedir [30]. 
GFTAA yönteminde, bir titreşim pikinin etrafında tanımlanan tek serbestlik dereceli Güç Spektral Yoğunluk fonksiyonu (GSY), Ters Ayrık Fourier Dönüşümü kullanılarak zaman tanım alanına geri dönüştürülebilmektedir. Doğal frekans zamana bağlı sıfır geçiş sayısının belirlenmesiyle, sönüm ise tek serbestlik dereceli normalize edilmiş oto korelasyon fonksiyonunun logaritmik azalışıyla belirlenebilmektedir [30]. GFTAA yönteminde ölçülmeyen etki kuvveti ve ölçülen davranış fonksiyonu arasındaki bağlantı Denklem (1) verilmektedir [31].

$$
G_{y y}(j \omega)=H(j \omega) * G_{x x}(j \omega) H(j \omega)^{T}
$$

Burada; $G_{x x}(j \omega)$ etki sinyalinin Güç Spektral Yoğunluk fonksiyonunu, $G_{y y}(j \omega)$ tepki sinyalinin Güç Spektral Yoğunluk fonksiyonunu ve $\mathrm{H}(\mathrm{j} \omega)$ frekans davranış fonksiyonunu ifade etmektedir. Matematiksel düzenlemelerden sonra tepki sinyaline ait GSY fonksiyonu tek kutuplu artık değer fonksiyonu formunda Denklem (2) verilmektedir.

$$
H(j w)=\sum_{k=1}^{n} \frac{R_{k}}{j \omega-\lambda}+\frac{R_{k}^{*}}{j \omega-\lambda_{k}^{*}}
$$

Burada; $n$ mod sayısını $\lambda_{k}$ kutup fonksiyonunu ve $R_{k}$ artık değer fonksiyonudur. Gerekli düzenlemeler yapıldıktan sonra Denklem 3 elde edilmektedir [32].

$$
G_{y y}(j \omega)=\sum_{k=1}^{n} \sum_{s=1}^{n}\left[\frac{R_{k}}{j \omega-\lambda_{k}}+\frac{R_{k}^{*}}{j \omega-\lambda_{k}^{*}}\right] G_{x x}(j \omega)\left[\frac{R_{s}}{j \omega-\lambda_{s}}+\frac{R_{s}^{*}}{j \omega-\lambda_{s}^{*}}\right]^{\bar{H}}
$$

Burada; s tekil değerleri, $\overline{\mathrm{H}}$ kompleks eşleniği ve transpozeyi ifade etmektedir. Matematiksel ifadeler sadeleştirildiğinde tepki sinyaline ait GSY fonksiyonu tek kutuplu artık değer fonksiyonu formunda Denklem 4 verilmektedir.

$$
G_{y y}(j \omega)=\sum_{k=1}^{n} \frac{A_{k}}{j \omega-\lambda \lambda_{k}}+\frac{A_{k}^{*}}{j \omega-\lambda_{k}^{*}}+\frac{B_{k}}{-j \omega-\lambda k}+\frac{B_{k}^{*}}{-j \omega-\lambda_{k}^{*}}
$$

Burada; Ak tepki sinyalinin GSY fonksiyonuna ait k. artık değer matrisini ifade etmektedir. GFTAA yönteminde ilk adım GSY matrisini belirlemektir. Ayrık frekanslarda tepki sinyalinin GSY'sinin tahmini $\omega=\omega_{\mathrm{i}}$ olarak bilinmekte ve tekil değer ayırışım matrisi alınarak ayrıştırılmaktadır [32].

$$
\mathrm{G}_{\mathrm{yy}}\left(\mathrm{j} \omega_{\mathrm{i}}\right)=\mathrm{U}_{\mathrm{i}} \mathrm{S}_{\mathrm{i}} \mathrm{U}_{\mathrm{i}}^{\overline{\mathrm{H}}}
$$

Burada; $U_{i}$ tekil vektörleri içeren bütün matrisi, $S_{i}$ skaler tekil değerleri içeren diyagonal matrisini ifade etmektedir. Denklem 5'te verilen GSY fonksiyonunda, pik değer yapan noktalar doğal frekanslara karşılık gelmektedir. Pik etrafındaki GSY fonksiyonundan elde edilen tek serbestlik dereceli tekil değer yoğunluk fonksiyonu kullanılarak doğal frekans ve sönüm elde edilmektedir. $\mathrm{Bu}$ işlem ters FFT yapılarak zaman ortamında doğal frekans ve sönüm elde edilebilmektedir. İki modun belirgin olması durumunda, birinci tekil vektör her zaman için iyi bir mod şekli ortaya çıkacaktır. Bununla birlikte, iki mod ortagonal olması durumunda, bu modlara ait tekil vektörler ilgili mod şekil vektörleridir [32]. 
Stokastik Altalan Belirleme (SAB) yöntemi korelasyon veya spektruma ihtiyaç duymadan doğrudan zaman verileriyle çalışan, zaman tanım alanına dayalı bir yöntemdir. $\mathrm{Bu}$ yöntem dinamik karakteristiklerin belirlenmesi için elverişlidir [33-34]. Bu yöntemde yap1 sisteminin dinamik davranışı lineer, sabit katsayılı ikinci derece diferansiyel denklem olarak Denklem 6'da verilmektedir.

$$
\ddot{M}(\mathrm{t})+\dot{C} \dot{U}(t)+K U(t)=R(t)=B u(t)
$$

Burada; $M, C, K$ sırasıyla sistemin kütle, sönüm ve rijitlik matrisleridir. $R(t)$ titreşim kuvvetini, $U(t)$, $\dot{U}(t), \ddot{U}(t)$ ise zamana bağlı yer değiştirme, hız ve ivme vektörlerini ifade etmektedir. Burada, $R(t)$ kuvvet vektörü, ortamdaki verileri simgeleyen $B$ matrisi ve $u(t)$ vektörü cinsinden ifade edilebilmektedir. Dinamik denge denklemi, Denklem 6, titreşen yapının davranışını temsil etmesine rağmen bu şekliyle SAB yöntemine uygun değildir. Bu yüzden, Denklem 6 daha uygun bir form olan ayrık-zaman stokastik durum-uzayı modeline dönüştürülmektedir.

$$
\left.\begin{array}{l}
x(t)=\left(\begin{array}{c}
U(t) \\
\dot{U}(t)
\end{array}\right) \\
A_{*}=\left(\begin{array}{cc}
0 & I_{n_{2}} \\
-M^{-1} K & -M^{-1} C
\end{array}\right) \\
B_{*}=\left(\begin{array}{c}
0 \\
M^{-1} B
\end{array}\right)
\end{array}\right\}
$$

Burada; $\mathrm{A}^{*}$ durum matrisini, $\mathrm{B}^{*}$ veri matrisini ve $\mathrm{x}(\mathrm{t})$ durum vektörünü ifade etmektedir. Çevresel titreşim testlerinde, yapının bütün serbestliklerini ölçmek pek mümkün olmamaktadır. Dolayısıyla, durum-uzay vektörünün eleman sayısı, sistemin durumunu tanımlayan bağımsız değişken sayısına eşittir ve gözlem denklemi Denklem 9'da verilmektedir.

$$
y(t)=C * x(t)+D * u(t)
$$

Burada; C sistem davranış matrisini, D doğrudan iletim matrisini ifade etmektedir. Örneklemeden sonra, durum-uzay modeli Denklem 10'da verilmektedir.

$$
\left.\begin{array}{l}
\mathrm{x}_{\mathrm{k}+1}=\mathrm{A} * \mathrm{x}_{\mathrm{k}}+\mathrm{B} * \mathrm{u}_{\mathrm{k}} \\
\mathrm{y}_{\mathrm{k}}=\mathrm{C} * \mathrm{x}_{\mathrm{k}}+\mathrm{D} * \mathrm{u}_{\mathrm{k}}
\end{array}\right\}
$$

Gerçek koşullarda yapılan ölçümler, yapıya ve dış ortamdaki gürültüye ait sinyalleri içermektedir. Dolayısıyla stokastik gürültü bileşenleri eklendiğinde belirli-stokastik durum-uzayı modeli,

$$
\left.\begin{array}{l}
\mathrm{x}_{\mathrm{k}+1}=\mathrm{A} * \mathrm{x}_{\mathrm{k}}+\mathrm{B} * \mathrm{u}_{\mathrm{k}}+\mathrm{w}_{\mathrm{k}} \\
\mathrm{y}_{\mathrm{k}}=\mathrm{C} * \mathrm{x}_{\mathrm{k}}+\mathrm{D} * \mathrm{u}_{\mathrm{k}}+\mathrm{v}_{\mathrm{k}}
\end{array}\right\}
$$


şeklindedir. Burada; $\mathrm{w}_{\mathrm{k}}$ modeldeki belirsizlikler ve kusurlar nedeniyle işlenen gürültü sinyallerini, $\mathrm{v}_{\mathrm{k}}$ ise ivmeölçer kusurlarından dolayı işlenen gürültü sinyalini ifade etmektedir. Her iki vektör de değeri ölçülemeyen sinyallerden oluşmaktadır. Etkisi olmayan beyaz gürültü ve kovaryans matrisleri,

$E *\left[\left(\begin{array}{c}w_{p} \\ v_{p}\end{array}\right)\left(\begin{array}{cc}w_{q}^{T} & v_{q}^{T}\end{array}\right)\right]=\left(\begin{array}{cc}Q & s \\ S^{T} & R\end{array}\right) \delta_{p q}$

şeklindedir [35]. Burada; E beklenen değer operatörünü, $\delta_{\mathrm{pq}}$ ise Kronecker deltasını ifade etmektedir. Kronecker delta iki değişkenli bir fonksiyondur ve Denklem 13 'te verilmektedir.

$\delta_{p q}=\left\{\begin{array}{l}1, \text { ĕger } p=q \\ 0, \text { eğer } p \neq q\end{array}\right.$

SAB yönteminde yapı sisteminin davranışı, normal koşullarda değeri ölçülemeyen sinyallerle titreştirilerek belirlenmektedir. $\mathrm{Bu}$ durumda, $\mathrm{U}_{\mathrm{k}}$ gürültü terimleri $\mathrm{w}_{\mathrm{k}} \mathrm{ve} \mathrm{v}_{\mathrm{k}}$ cinsinden yazılırsa yapının ayrık-zaman stokastik durum-uzay modeli,

$$
\left.\begin{array}{l}
\mathrm{x}_{\mathrm{k}+1}=\mathrm{A} * \mathrm{x}_{\mathrm{k}}+\mathrm{w}_{\mathrm{k}} \\
\mathrm{y}_{\mathrm{k}}=\mathrm{C} * \mathrm{x}_{\mathrm{k}}+\mathrm{v}_{\mathrm{k}}
\end{array}\right\}
$$

şeklindedir. Denklem 14, çevresel titreşimlerden dinamik karakteristiklerin belirlenmesinde zaman alanının temelini oluşturmaktadır.

\section{III. İLYASBEY CAMISI'NE AİT BİLGILER}

İlyasbey Camisi Aydın ili, Didim ilçesi, Akyeniköy Beldesi, Balat Köyünde Miletos kentinin kalıntıları üzerinde bulunmaktadır. İlyasbey Camisi kare planlı olup, bir kenarı yaklaşık $18.30 \mathrm{~m}$ uzunluğundadır (Şekil 1). Caminin ana taşıyıcı duvarları yaklaşık 9m yüksekliğe kadar devam etmektedir. Bu seviyeden sonra sekizgen geçiş bölgesi ve kubbe bulunmaktadır. Kubbe üstü tepe noktası zeminden yaklaşık 20m yüksekliğe sahiptir. İlyasbey Camisi Minaresi 1955 tarihinde meydana gelen depremde yıkılmıştır. Daha sonra yapılan restorasyon uygulamalarında İlyasbey Cami Minaresi tamamlanmıştır. İlyasbey Cami Minaresi'nin kaide ve geçiş bölgesi malzemesi mermer, silindirik gövdesi ve petek kısmı ise tuğladır.
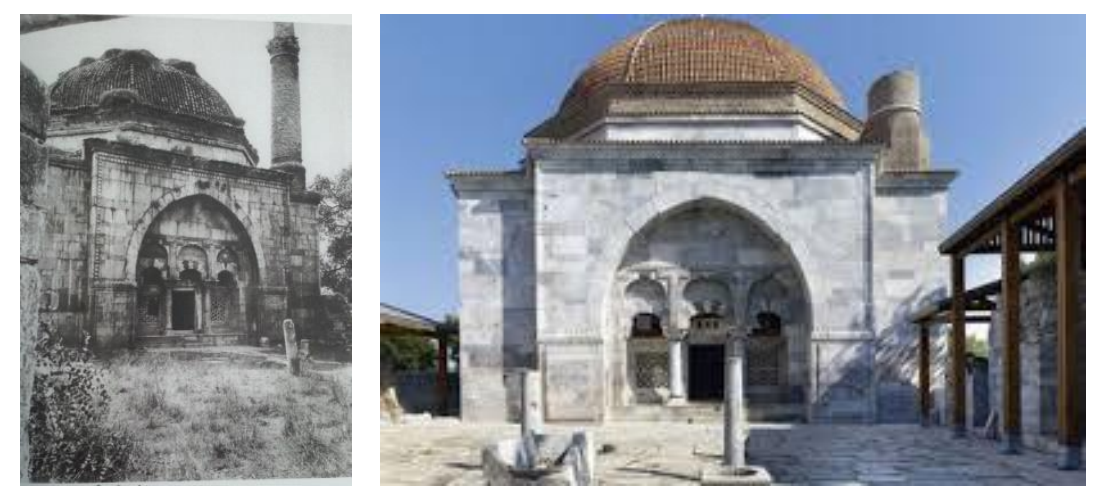

Şekil 1. İlyasbey Camisi’ne ait görüntüler 


\section{A. MIMMARİ VE YAPISAL ÖZELLİKLER}

İlyasbey Camisi kare planlı bir yapı olup, mukarnas dolgulu tromplarla geçilen bir kubbe ile örtülüdür. Camiye kuzey cephesinden girilmektedir. Simetrik düzene sahip bu cephede $0.7 \mathrm{~m}$ kadar dişarı taşan sivri kemerli portal niş bulunmaktadır. Bu nişin içinde iki sütunla desteklenen basık kemerli üç açıklık yer almaktadır (Şekil 2). Giriş kapısının iki yanında geometrik bezemeli açıklıklar bulunur. Doğu, batı ve güney cephelerde ise altta demir parmaklıklı üstte alçı örgülü ikişer adet pencere mevcuttur (Şekil $3)$.
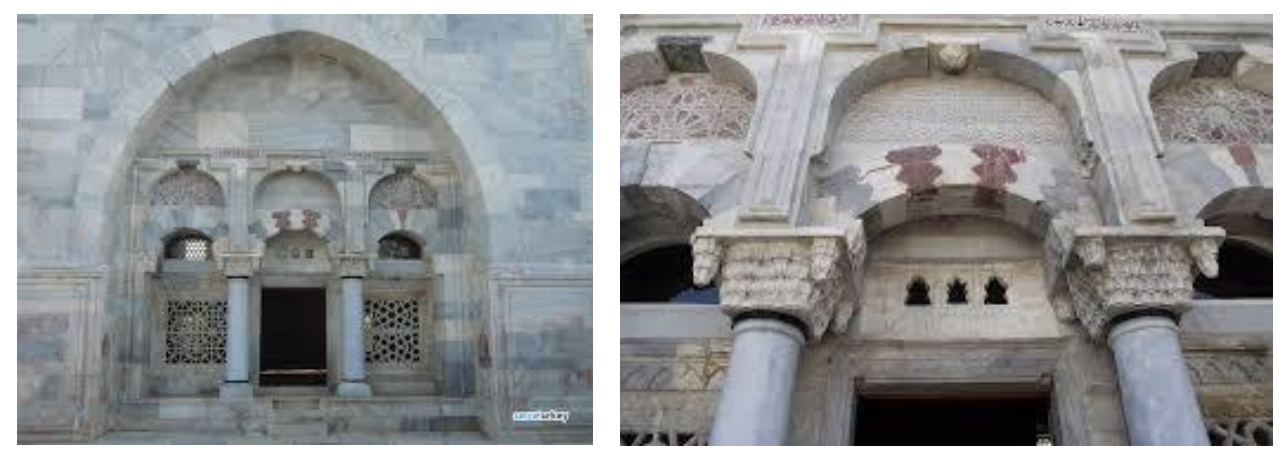

Şekil 2. Ilyasbey Camisi’nin kuzey cephesine ait görüntüler
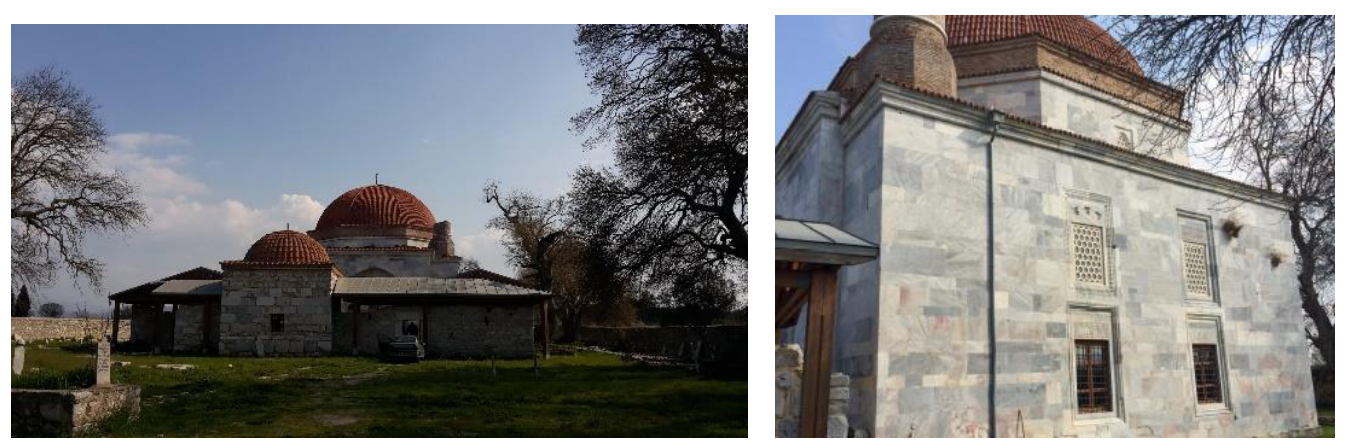

Şekil 3. Illyasbey Camisi'nin doğu, batı ve güney kuzey cephelerine ait görüntüler

İlyasbey Camisi'nin kasnak ve kubbesi, dolu tuğladan inşa edilmiştir. Kasnağın doğu, batı ve güney cephelerinde altta yarım daire kemerli ve örgülü birer pencere bulunmaktadır (Şekil 4). Caminin kuzey köşesinde ise minaresi bulunmaktadır.
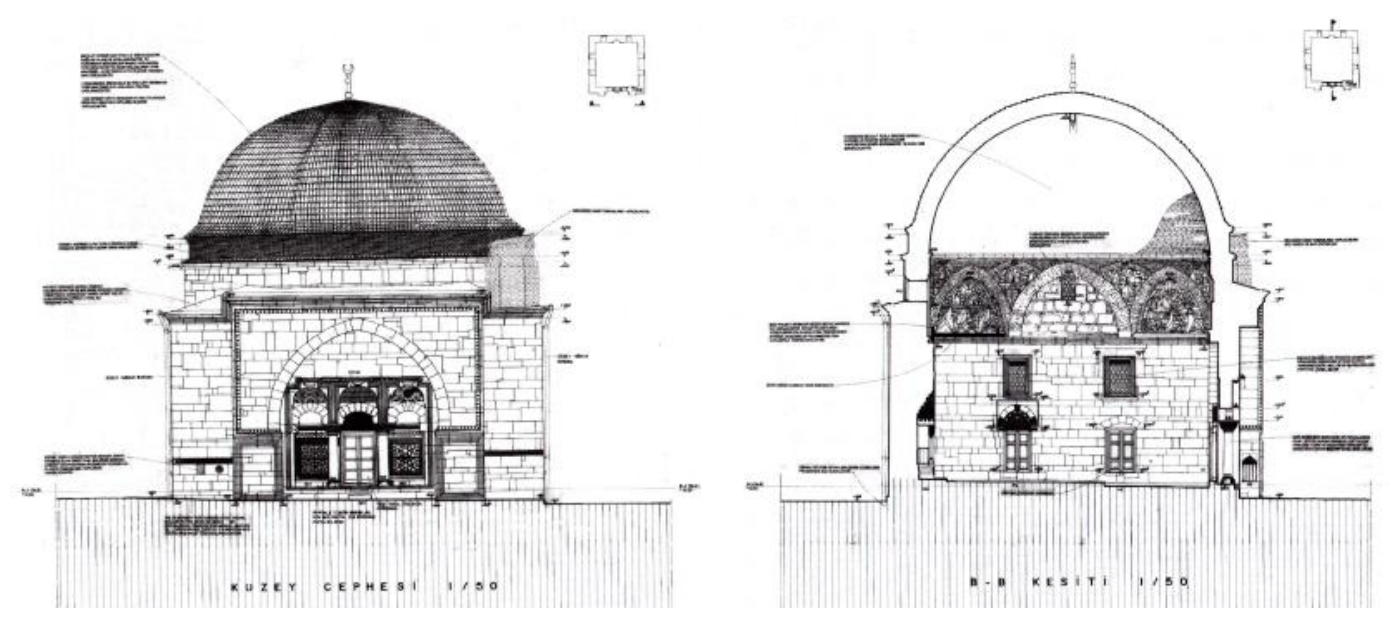


\section{B. ZEMIN VE TEMEL İNCELEMESI}

Şekil 4. Illyasbey Camisi ’nin tuğla kubbesi, kasnak bölgesine ait görüntüler

İlyasbey Camisi’nin bulunduğu bölgede jeolojik ve jeofizik incelemeler yapılarak zemin özellikleri belirlenmeye çalışılmıştır. Bu amaçla 20m derinliğinde, 2 adet sondaj kuyusu, 2 ayrı serimde sismik kırılma ölçümü MASW ve 1 adet temel gözlem çukuru açllarak temel ve zemin yapısı, zeminle ilgili parametreler ve statik ve deprem hesaplarına ilişkin katsayılar belirlenmeye çalışılmıştır (Şekil 5-6). Gerçekleştirilen incelemeler neticesinde,

- Caminin deniz seviyesinden 4-5m yüksekliğinde olduğu,

- Cami temellerinin yüzeyden $3 \mathrm{~m}$ aşağıda olduğu,

- Cami temelinin yaklaşık 19x19m boyutunda olduğu,

- Temel sisteminin mermer bloklar ile oluşturulduğu,

- Zemin türünün gevsşek kuru kum olduğu,

- Zeminin kohezyon değerinin 0 , içsel sürtünme açısının 28-30 olduğu,

- Yüzeyin $50 \mathrm{~cm}$ altında yeraltı suyunun bulunduğu,

- Zeminin deprem etkisinde sıvalaşma potansiyelinin oldukça yüksek olduğu,

- Zemin büyütme katsayısının 2.88 olduğu,

- Zemin yoğunluğunun $1.58-1.80 \mathrm{gr} / \mathrm{cm}^{3}$ arasında olduğu,

- Zemin Poisson oranının 0.34-0.41 arasında olduğu,

- Zemin elastisite modülünün $395-2296 \mathrm{~kg} / \mathrm{m}^{2}$ arasında olduğu,

- Zemin emniyetli taşıma değerinin $0.96 \mathrm{~kg} / \mathrm{cm}^{2}$ olduğu,

- Zemin yatak katsayısının $1980 \mathrm{t} / \mathrm{m}^{3}$ olduğu,

- Zeminde oturmaların tamamlandığı ve bundan sonraki süreçte herhangi bir oturma beklenilmediği,

- Minarenin tamamlanmasıyla oluşacak ilave yükten dolayı zeminde oturma veya taşıma gücü kaybı meydana gelmesinin beklenilmediği

belirlenmiştir [36].
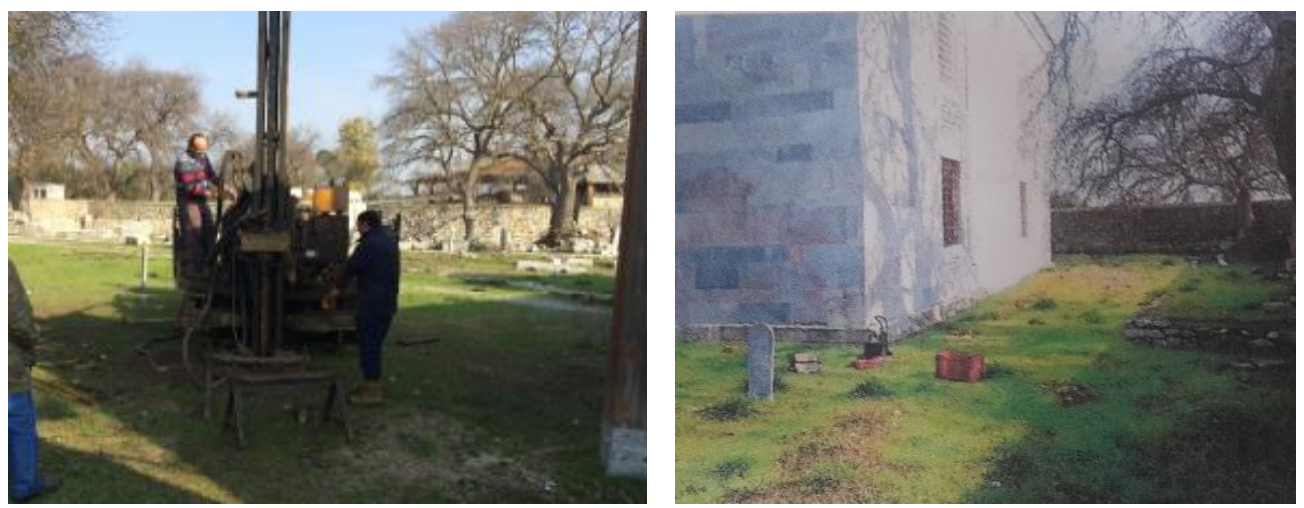

Şekil 5. İlyasbey Camisi'nin bulunduğu bölgede gerçekleştirilen sondaj incelemelerine ait görüntüler 

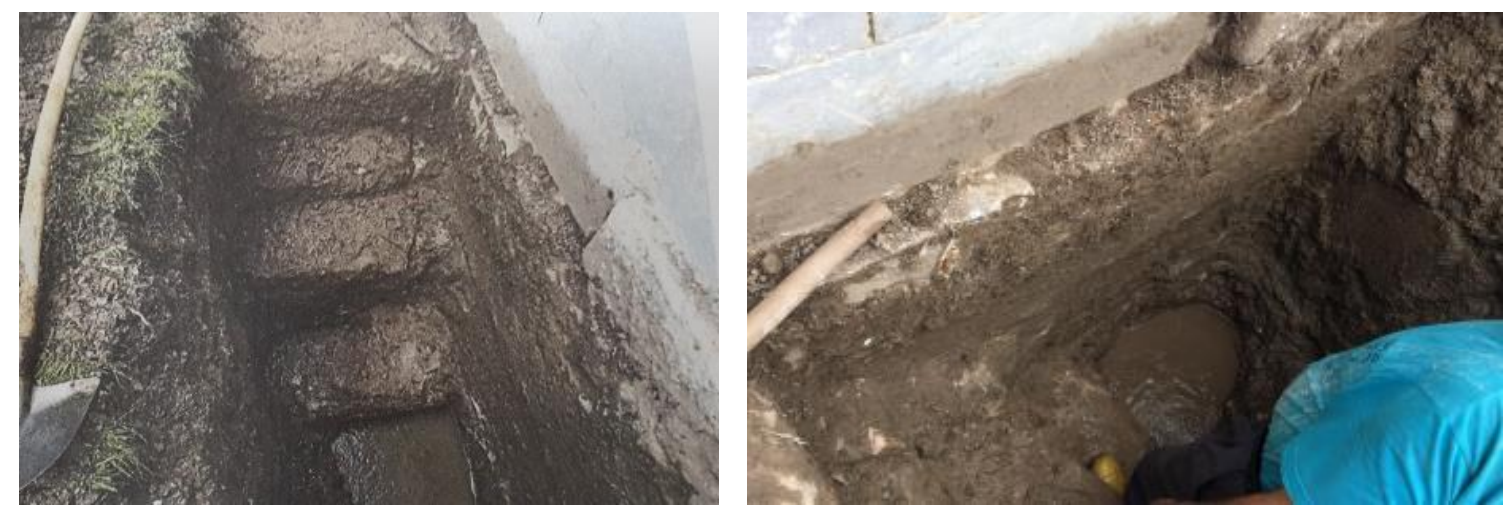

Şekil 6. Illyasbey Camisi'nin bulunduğu bölgede temel gözlem çukuru incelemesine ait görüntüler

\section{DEPREM PARAMETRELERİ}

İlyasbey Camisinin bulunduğu Aydın ili, Didim ilçesi Menderes Grabeni içerisindedir. Dolayısıyla bölge Menderes Grabenini oluşturan ve günümüzde de aktif olan Büyük Menderes fayının etkisindedir (Şekil 7). İlyasbey Camisi'nin bulunduğu alanda gerçekleştirilen jeolojik ve jeofizik incelemeler neticesinde, caminin bulunduğu bölgenin zemin yapısının gevşek kuru kum olduğu belirlenmiştir [36]. Deprem Yer Hareketi Düzeyi-2 (DD-2), spektral büyüklüklerin 50 yılda aşılma olasıllığının \%10 ve buna karşı gelen tekrarlanma periyodunun 475 y1l olduğu seyrek deprem yer hareketini nitelemektedir. $\mathrm{Bu}$ deprem yer hareketi, standart tasarım deprem yer hareketi olarak da adlandırılmaktadır. Yapının bulunduğu bölge için deprem karakteristikleri ve spektrumlar aşağıdaki gibi belirlenmiştir [37] (Şekil 8):

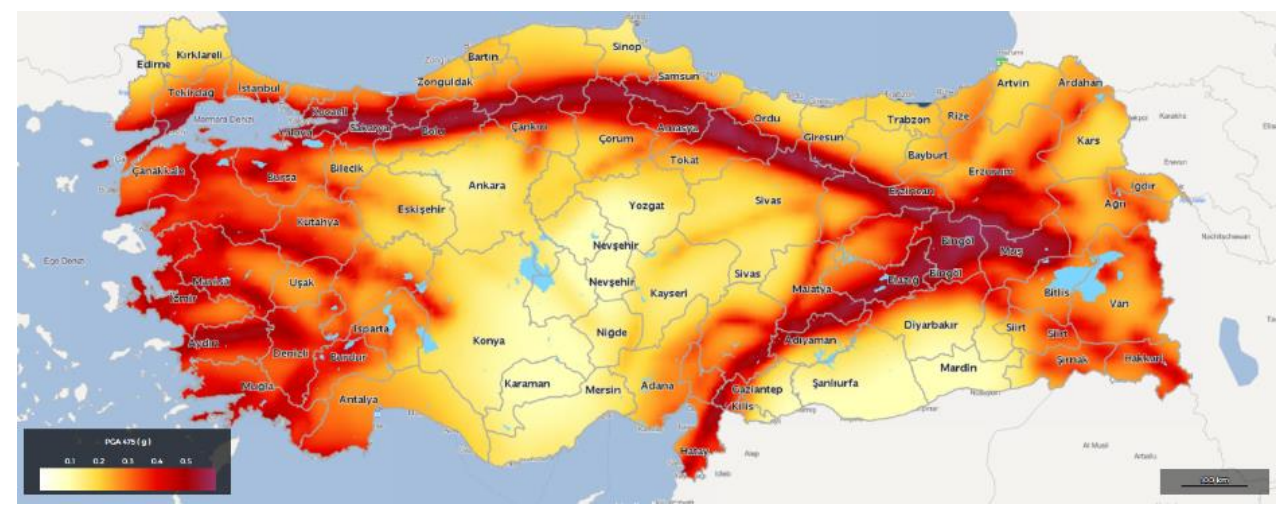

Şekil 7. Deprem Yer Hareketi Düzeyi-2 için Türkiye Deprem Tehlike Haritası

\section{$\mathrm{S}_{\mathrm{S}}=0.980$ \\ $\mathrm{S}_{1}=0.233$}

Yerel Zemin Sınıfı ZE ve $S_{S}=0.473$ için

Yerel Zemin Sınıfı ZE ve $S_{1}=0.159$ için

Tasarım Spektral İvme Katsayıları

Yatay Elastik Tasarım Spektrumu

$$
\begin{aligned}
& P G A=0.407 \\
& F_{S}=1.116 \\
& F_{1}=3.135 \\
& S_{D S}=1.094 \\
& T_{A}=0.134 \mathrm{~s}
\end{aligned}
$$$$
\mathrm{PGV}=22.222
$$ 

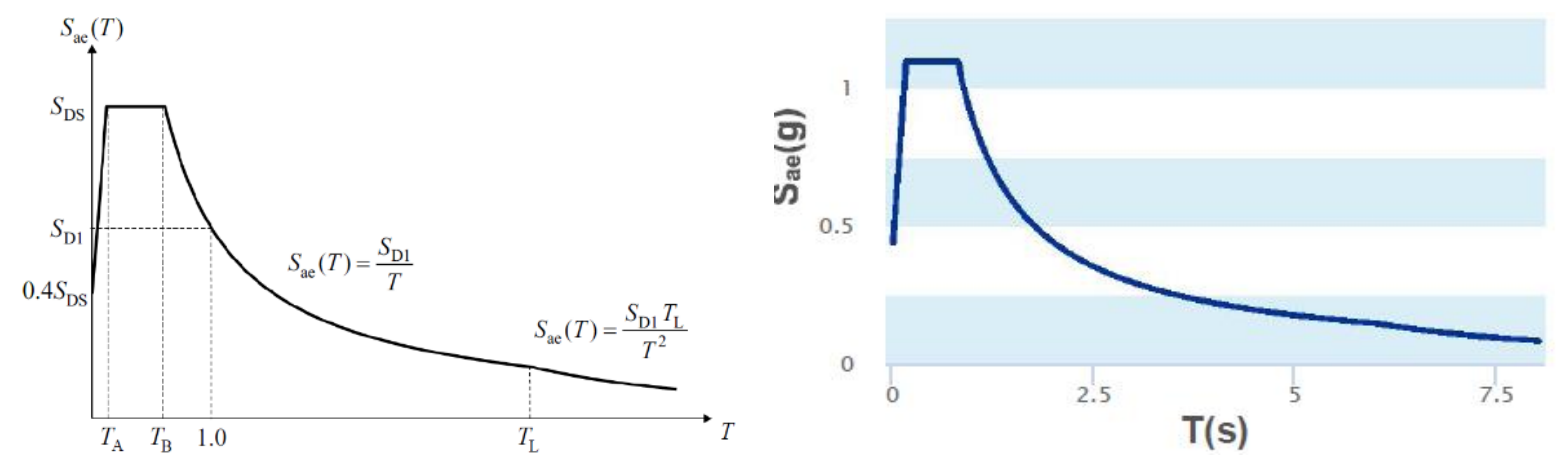

Şekil 8. Türkiye Bina Deprem Yönetmeliği’ne göre tasarım spektrumu (DD-2)

\section{CEVRESEL TITRESSIM TESTI}

İlyasbey Camisi'nin dinamik ölçümleri çevresel titreşimler altında Çevresel Titreşim Testi (Operasyonal Modal Analiz) Yöntemiyle gerçekleştirilmiştir. Cami üzerindeki ölçümde toplam 8 adet sismik ivmeölçer kullanılmıştır. İvmeölçerler caminin hem enine hem de boyuna doğrultudaki hareketlerini ölçebilecek şekilde yerleştirilmiştir. İvmeölçerlerde gelen sinyaller 17 kanallı veri toplama ünitesine aktarılmıştır. Veri toplama ünitesinden bilgisayar ortamına aktarılan sinyaller PULSE ve OMA [38-39] yazılımlarında işlenmiştir. Toplam 60dk süre taşıt yükü, rüzgâr yükü ve diğer çevresel titreşimler altında caminin davranışı izlenmiş ve dinamik parametreler olarak adlandırılan doğal frekanslar, modal sönüm oranları ve mod şekilleri belirlenmiştir. İlyasbey Camisi'nde gerçekleştirilen ölçüme ait bazı görüntüler Şekil 9'da verilmektedir.

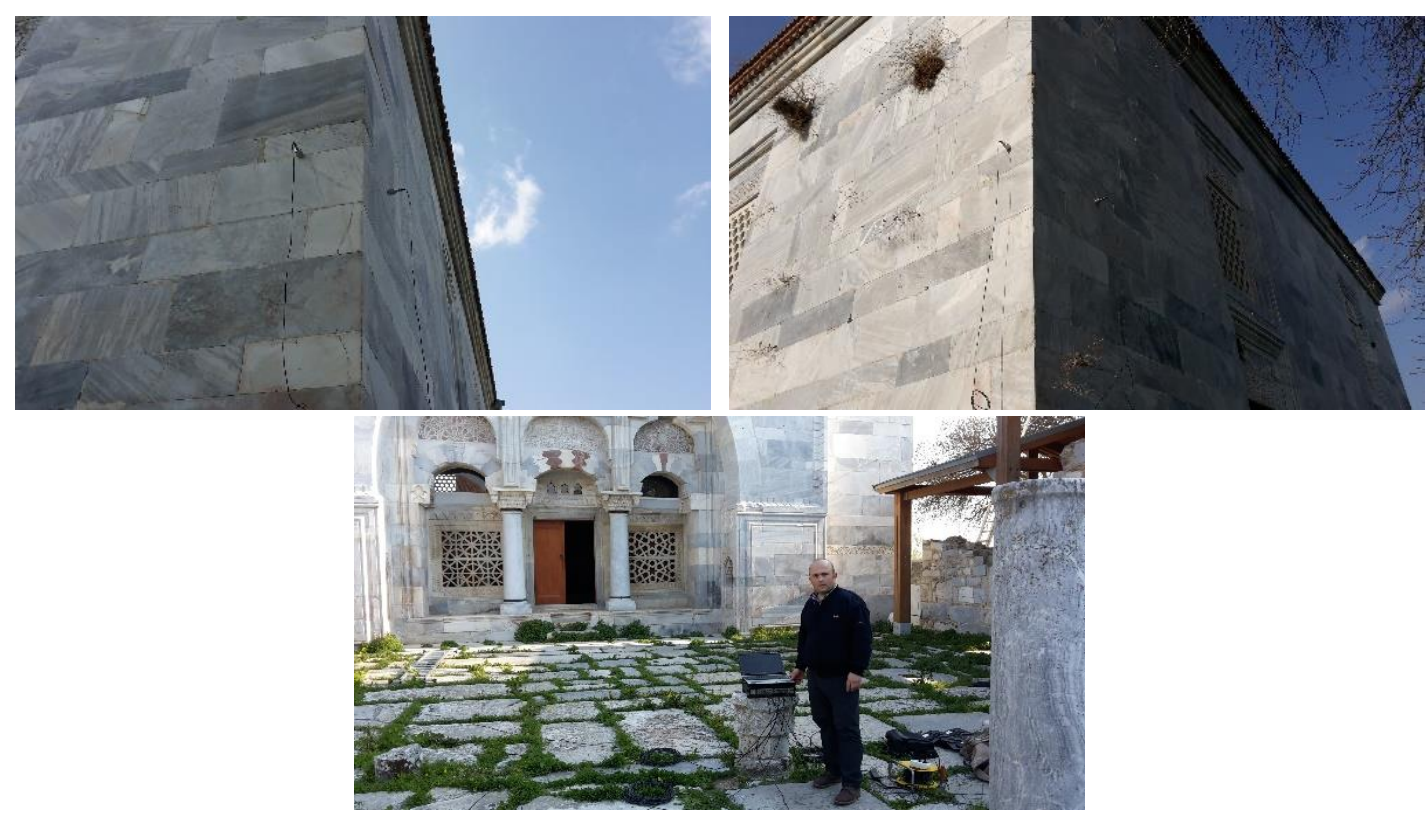

Şekil 9. Illyasbey Camisi’nin Çevresel Titreşim Testine ait görüntüler

Ölçümlerde ivmeölçerler cami duvarlarının üst köşelerine her iki yönde bağlanmıştır. Cami üzerindeki ölçüm işleminde kullanılan ivmeölçer yerleşim düzeni Şekil 10'da verilmektedir. 


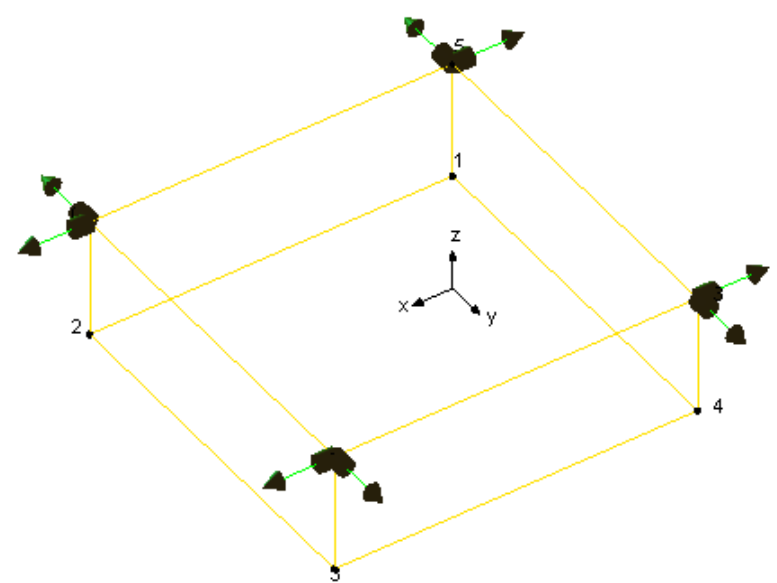

Şekil 10. Illyasbey Camisi'nin Çevresel Titreşim Testi ölçümlerinde ivmeölçer yerleşim düzeni

Caminin başlangıç Sonlu Eleman modeli üzerinde gerçekleştirilen modal analiz sonuçları dikkate alınarak çevresel titreşim testi ölçümü $0-25 \mathrm{~Hz}$ frekans aralığında gerçekleştirilmiştir. Ölçümünden elde edilen titreşim sinyallerinin Fourier dönüşümleri yapılmış ve spektrumlar elde edilmiştir. Caminin dinamik karakteristikleri, Geliştirilmiş Frekans Tanım Alanında Ayrıştırma (GFTAA) Yöntemi'yle belirlenmiştir. Her bir kanaldaki sinyal için elde edilen spektral yoğunluk fonksiyonları ve tekil değerler Şekil 11'de verilmektedir.

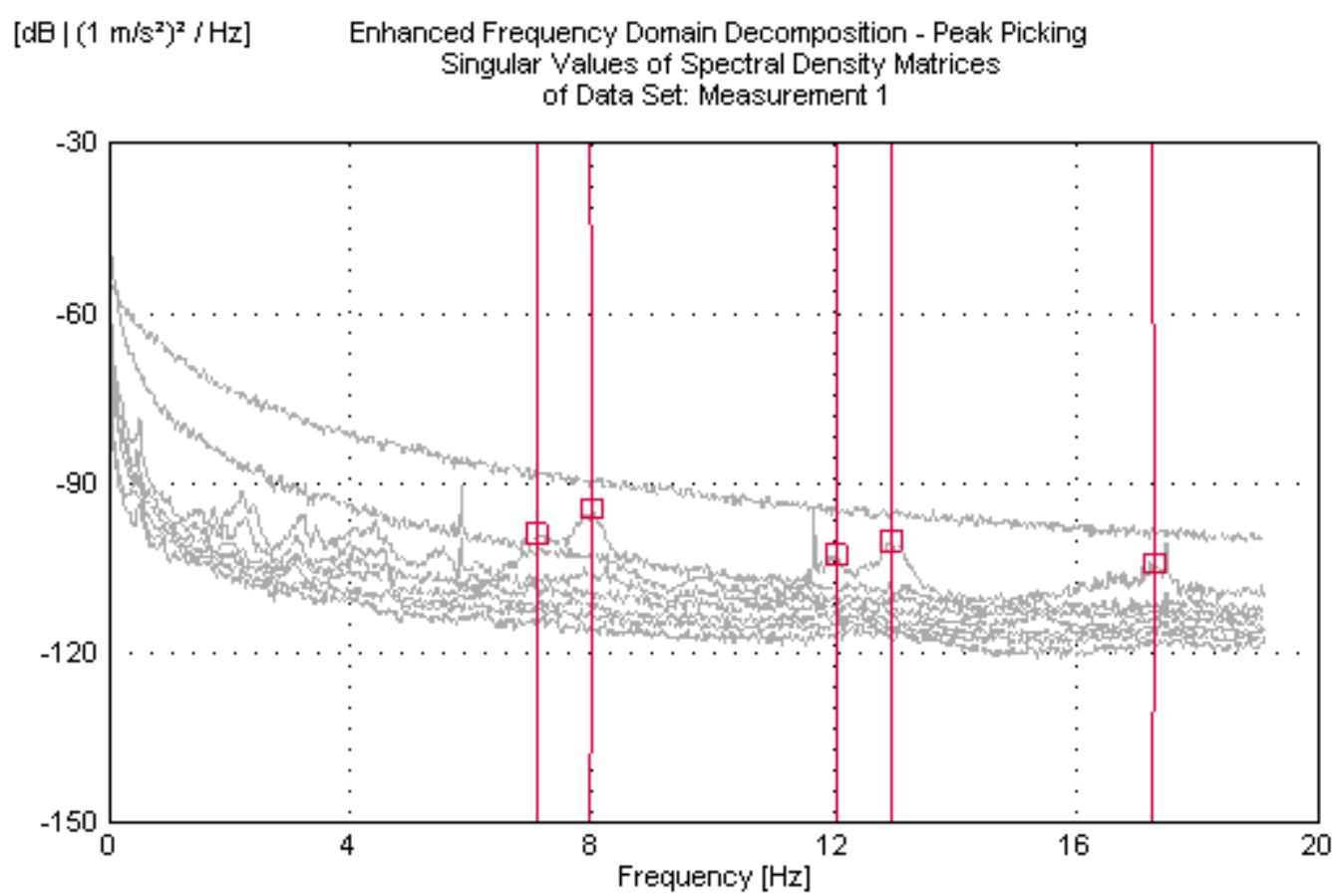

Şekil 11. Cami’nin GFTAA Yöntemiyle elde edilen spektral yoğunlukfonksiyonu ve tekil değerleri

$\mathrm{Bu}$ grafiklerdeki tepe değerler caminin frekanslarını temsil etmektedir. Şekil 10'dan ölçüm yapılan 0$25 \mathrm{~Hz}$ frekans aralı̆̆ında ilk dört modun elde edildiği görülmektedir. Bu modlara ait frekans ve modal sönüm oranı değerleri Tablo 1'de verilmektedir. 
Tablo 1. Ilyasbey Camisi'nin Çevresel Titreşim Testinden ölçülen doğal frekansları ve sönüm oranları

\begin{tabular}{lll}
\hline Mod Numarası & Doğal Frekans $(\mathrm{Hz})$ & Modal Sönüm Oranı $(\%)$ \\
\hline 1 & 7.083 & 0.456 \\
2 & 7.966 & 1.783 \\
3 & 12.03 & -- \\
4 & 12.96 & 1.914 \\
\hline
\end{tabular}

İlyasbey Camisi'nin Çevresel Titreşim Testi'nden elde edilen ilk dört deneysel mod şekilleri ise Şekil 12 'de verilmektedir.

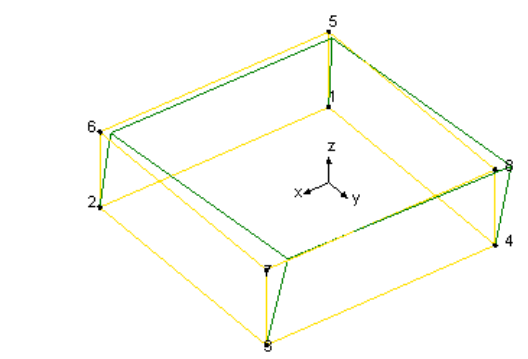

Birinci Mod (Doğu-Batı Ötelenme Modu)

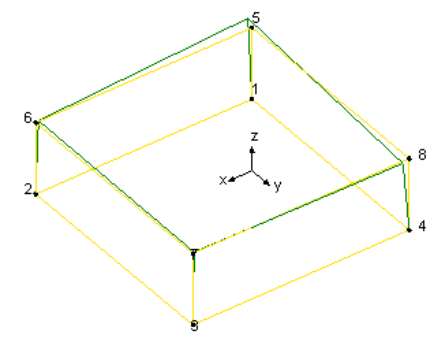

Üçüncü Mod (Burulma Modu)

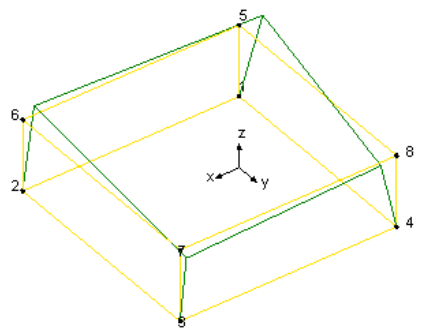

İkinci Mod (Kuzey-Güney Ötelenme Modu)

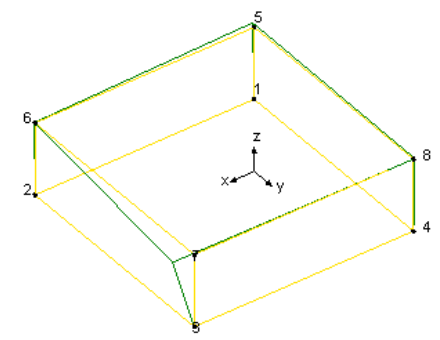

Dördüncü Mod (Burulma Modu)

Şekil 12. Ilyasbey Camisi 'nin Çevresel Titreşim Testinden elde edilen ilk dört mod şekli

\section{SONLU ELEMAN MODELI VE MODAL ANALIZ}

\section{A. BAŞLANGIÇ ANALITIKK MODEL}

İlyasbey Camisi'nin mevcut durumu temsil edecek şekilde SAP2000 [40] programında başlangıç analitik model oluşturulmuştur. Bu modelin oluşturulmasında caminin rölöve işlemleri sonucunda elde edilen çizimlerdeki boyutlar dikkate alınmıştır. Malzeme özellikleri olarak ise benzer uygulamalarda kullanılan ve literatürde önerilen mekanik değerler (elastisite modülü, poisson oranı ve birim ağırlık) dikkate alınmıştır. Tablo 2'de caminin başlangıç analitik modelinin oluşturulmasında kullanılan malzemeler için dikkate alınan mekanik özellikler verilmektedir. 
Tablo 2. Illyasbey Camisi'nin başlangıç analitik modeli için her bir elemanın malzeme özellikleri

\begin{tabular}{l|llll}
\hline \multicolumn{1}{l}{ Malzeme } & & Elastisite Modülü $\left(\mathrm{N} / \mathrm{m}^{2}\right)$ & Poisson Oranı & Yoğunluk $\left(\mathrm{kg} / \mathrm{m}^{3}\right)$ \\
\hline \multirow{4}{*}{ Cami } & Gövde & $2.00 \times 1010$ & 0.20 & 2400 \\
& Kasnak & $2.00 \times 1010$ & 0.20 & 2400 \\
& Kubbe & $2.00 \times 109$ & 0.20 & 1600 \\
& Temel & $2.00 \times 1010$ & 0.20 & 2400 \\
\hline \multirow{3}{*}{ Minare } & Çekirdek & $2.00 \times 1010$ & 0.20 & 2400 \\
& Merdiven & $2.00 \times 1010$ & 0.20 & 2400 \\
& Cidar & $2.00 \times 109$ & 0.20 & 1600 \\
\hline \hline
\end{tabular}

Caminin modellenmesinde her bir noktasında üç serbestliği olan sekiz düğüm noktalı 112306 adet katı eleman kullanılmıştır. Analitik modelin oluşturulmasında cami duvarları, kasnağı, kubbesi ve temeli ile minarenin çekirdeği, basamakları ve cidarı farklı malzeme özellikleri kullanılarak modellenmiştir. Minarenin yıkılmış olduğu durum için oluşturulan başlangıç analitik modelin modal analizi gerçekleştirilmiştir. Başlangıç analitik modelden elde edilen doğal titreşim frekans değerleri Tablo 3'te verilmektedir.

Tablo 3. İlyasbey Cami Minaresinin yıkık olduğu durum için başlangıç analitik modelin doğal frekansları

\begin{tabular}{cc}
\hline \hline Mod Numarası & Doğal Frekans $(\mathrm{Hz})$ \\
\hline 1 & 8.144 \\
2 & 9.185 \\
3 & 13.258 \\
4 & 13.968 \\
\hline
\end{tabular}

\section{B. MODEL KALİBRASYONU VE KALİBRE EDİLMIŞ ANALITİK MODEL}

İlyasbey Camisi'nin mevcut durumu temsil edecek şekilde oluşturulan başlangıç Sonlu Eleman modelinin, cami üzerinde gerçekleştirilen Çevresel Titreşim Testi sonuçlarına göre kalibre edilmesi gerekmektedir. $\mathrm{Bu}$ amaçla başlangıç Sonlu Eleman modelde gerek malzeme özelliklerinin seçiminde gerekse mesnet şartlarının tanımlanmasında yapılan kabullerin, yerinde yapılan gözlemler neticesinde makul değerler aralığında değiştirilerek deneysel ve analitik sonuçların örtüşmesi sağlanmalıdır. İlyasbey Camisi'nin başlangıç analitik modelinden elde edilen frekanslar ile Çevresel Titreşim Testi'nden elde edilen frekans değerleri ve farklar Tablo 4'te verilmektedir. İlyasbey Camisi'nin başlangıç analitik modeli üzerinde, yerinde yapılan gözlemler doğrultusunda deneme yanılma yöntemiyle gerçekleştirilen kalibrasyon işlemi sonucunda elde edilen frekans değerleri ve farklar ise Tablo 5'te verilmektedir.

Tablo 4. İlyasbey Camisi Minaresinin yıkık olduğu durum için deneysel ve başlangıç analitik doğal frekansları

\begin{tabular}{cccc}
\hline \hline \multirow{2}{*}{ Mod Numarası } & \multicolumn{2}{c}{ Doğal Frekans (Hz) } & \multirow{2}{*}{ Fark (\%) } \\
\cline { 2 - 3 } & Deneysel & Başlangıc Analitik & \\
\hline 1 & 7.083 & 8.144 & +14.98 \\
2 & 7.966 & 9.185 & +15.30 \\
3 & 12.03 & 13.258 & +10.21 \\
\hline
\end{tabular}


Kalibrasyon işleminde zemin yatak katsayısının değişken olduğu kabul edilmiştir. Kalibrasyon işlemiyle deneysel ve teorik frekanslar arasında başlangıç durumda ortalama \%12.1 olan fark, kalibrasyon işlemi sonrasında ortalama \%3.67'ye kadar azaltılabilmiştir. Bu durumda kalibre edilen analitik modelin mevcut caminin davranışını daha gerçekçi temsil ettiği kabul edilmektedir.

Tablo 5. İlyasbey Camisi Minaresinin yıkık olduğu durum için deneysel ve kalibre analitik doğal frekansları

\begin{tabular}{cccc}
\hline \hline \multirow{2}{*}{ Mod Numarası } & \multicolumn{2}{c}{ Doğal Frekans $(\mathrm{Hz})$} & \multirow{2}{*}{ Fark $(\%)$} \\
\cline { 2 - 3 } & Deneysel & Başlangıç Analitik & \\
\hline 1 & 7.083 & 6.886 & -2.78 \\
2 & 7.966 & 7.862 & -1.31 \\
3 & 12.03 & 12.836 & +6.69 \\
4 & 12.96 & 13.467 & +3.91 \\
\hline \hline
\end{tabular}

İlyasbey Cami Minare modeli, kürsü seviyesinde $2.5 \mathrm{~m}$ çapında olup, $60 \mathrm{~cm}$ kalınlıktadır. Gövde bölgesinde minare çapı altta $2.1 \mathrm{~m}$ ve duvar kalınlığ $140 \mathrm{~cm}$ iken, üstte $2.0 \mathrm{~m}$ çapında olup $35 \mathrm{~cm}$ duvar kalınlığındadır. Şerefenin üst kısmında gövde çap $1.65 \mathrm{~m}$ olup, duvar kalınlığı $17.5 \mathrm{~cm}$ düzeyindendir. Minarenin çekirdeği $30 \mathrm{~cm}$ çapındadır. Bu bilgiler 1şı̆̆ında tamamlanan minareli durum için oluşturulan Sonlu Eleman modeline ait görüntüler Şekil 13'te verilmektedir. Bu durum için oluşturulan Sonlu Eleman modelinde 135487 adet düğüm noktası ve 114148 adet katı eleman kullanılmıştır. Analitik modelin oluşturulmasında cami duvarları, kasnağı, kubbesi ve temeli ile minarenin çekirdeği, basamakları ve cidarı ayrı ayrı ve farklı malzeme özellikleri kullanılarak modellenmiştir.
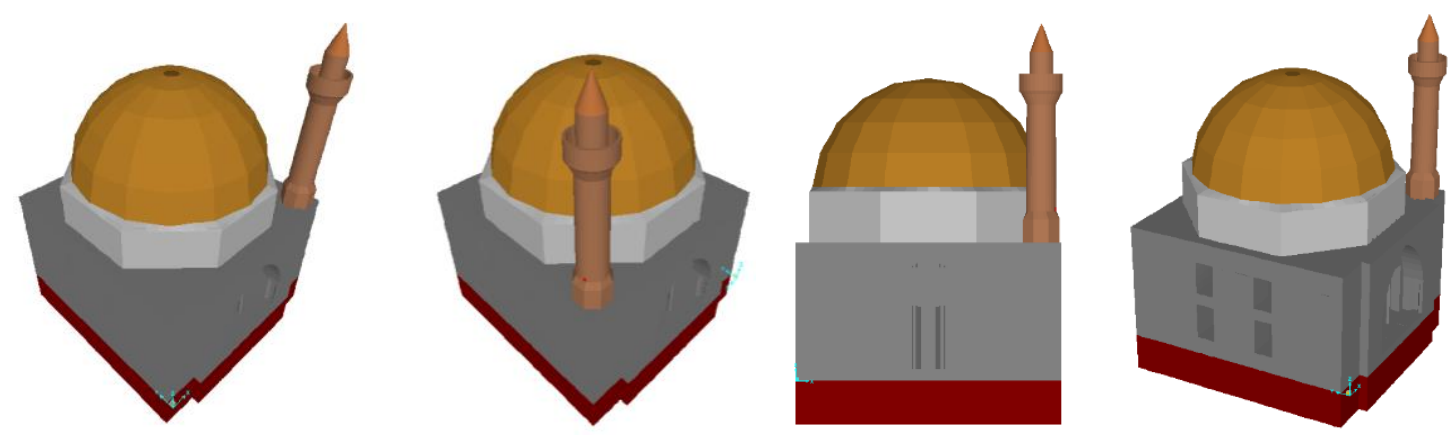

Şekil 13. Ilyasbey Camisi’nin SAP2000 programında oluşturulan analitik model

İlyasbey Camisi için elde edilen doğal titreşim frekans değerleri Tablo 6'da ve ilk dört mod şekli Şekil 14 'te verilmektedir.

Tablo 6. Ilyasbey Camisi’nin analitik modelin doğal frekanslarl

\begin{tabular}{ll}
\hline \hline Mod Numarası & Doğal Frekans $(\mathrm{Hz})$ \\
\hline 1 & 5.023 \\
2 & 6.880 \\
3 & 7.889 \\
4 & 11.769 \\
\hline \hline
\end{tabular}



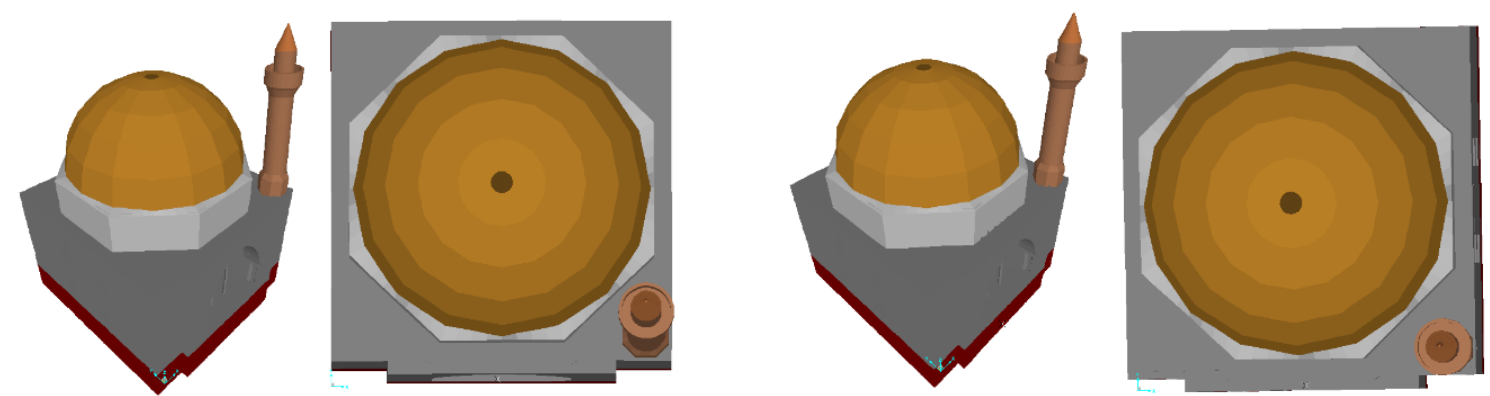

Birinci Mod (Kuzey-Güney doğrultusunda ötelenme hareketi) İkinci Mod (Doğu-Batı doğrultusunda ötelenme)
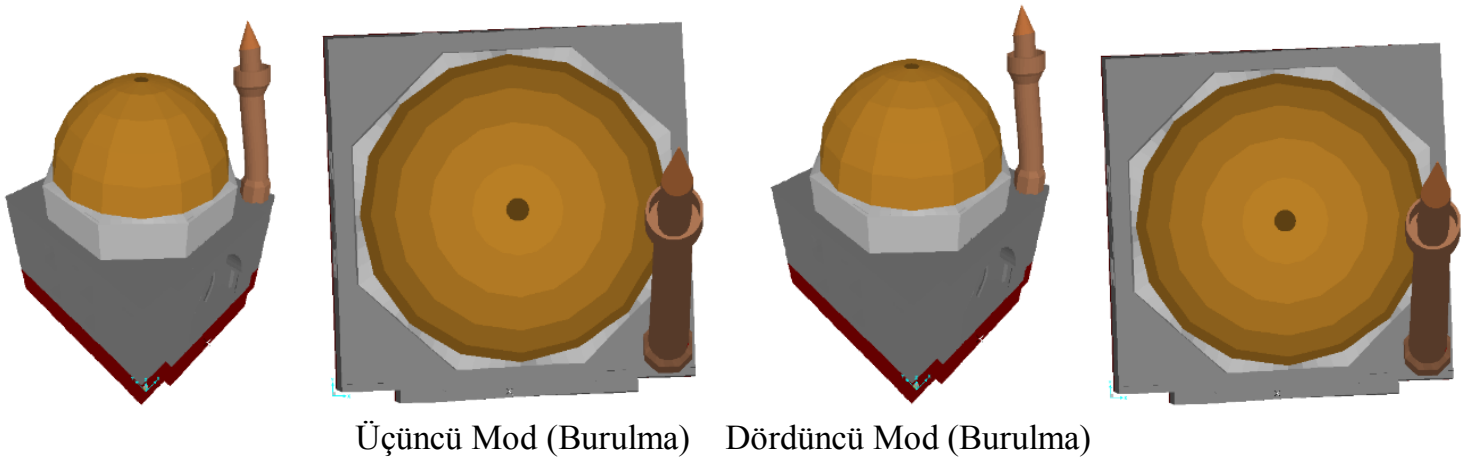

Şekil 14. İlyasbey Camisi için analitik modelin mod şekilleri

\section{YAPISAL ANALIZLLER VE DEĞERLENDİRMELER}

İlyasbey Camisi ve Minaresi'nin sabit yük etkisindeki yapısal davranışını belirleyebilmek amacıyla, malzemenin birim hacim ağırlığı ile orantılı olarak sabit yükler (düşey yükler) SAP2000 programı tarafından otomatik olarak hesaplanmaktadır. İlyasbey Camisi Minaresi'nin rüzgâr yüklerine karş1 analizinde, TS498 standardı ve yapıya en yakın meteoroloji istasyonuna ait geçmiş yılların verileri dikkate alınmıştır. Rüzgârın oluşturacağı emme ve basınç kuvvetleri, cami gövdesinde normal yapılara göre hesaplanırken, minarede kule tipi yapılara göre hesaplanmıştır [41]. İlyasbey Camisi'nin bulunduğu bölge için meteorolojik kayıtlardan 19.04 .1969 tarihinde $106.2 \mathrm{~km} / \mathrm{sa}$ hızında en yüksek rüzgâr hızının ölçüldüğü belirlenmiştir. İlyasbey Cami Minaresi'nin deprem etkisindeki davranışı, deprem tehlike haritasında tanımlanan ve 50 yıllık referans süre içerisinde $\% 10$ aşılma olasıllı̆̆ için bölgenin depremselliği, zemin bilgileri ve yapı özellikleri göz önüne alınarak Davranış Spektrumu Yöntemiyle gerçekleştirilmiştir. Dinamik analizlerde sönüm oranı olarak deneysel ölçümden elde edilen sönüm değerleri dikkate alınmıştır.

İlyasbey Camisi ve Minaresi için oluşturulan analitik model üzerinde lineer statik ve dinamik analizler gerçekleştirilmiştir. Bu yüklemeler altında yapılan analizler sonrasında her bir durum için camide ve minarede oluşan yerdeğiştirmeler, çekme, basınç ve kayma gerilmeleri hesaplanmıştır.

\section{A. SABİT YÜK ETKİSINDEKİ DAVRANIŞIN BELİRLENMESİ}

İlyasbey Camisi ve Minaresi'nin tamamlandığı durum için sabit yük etkisinde gerçekleştirilen analizinden, yapıda oluşan yerdeğiştirmeler ile çekme, basınç ve kayma gerilmelerinin dağılımları elde edilmiştir. Yapının sabit yük etkisinde yerdeğiştirmiş hali Şekil 15'te, gerilme dağılımları ise Şekil 16 'da verilmektedir. Bu durumda minarede maksimum yerdeğiştirme minarenin tepe noktasında düşey yönde $1.350 \mathrm{~mm}$ olarak meydana gelmiştir. 

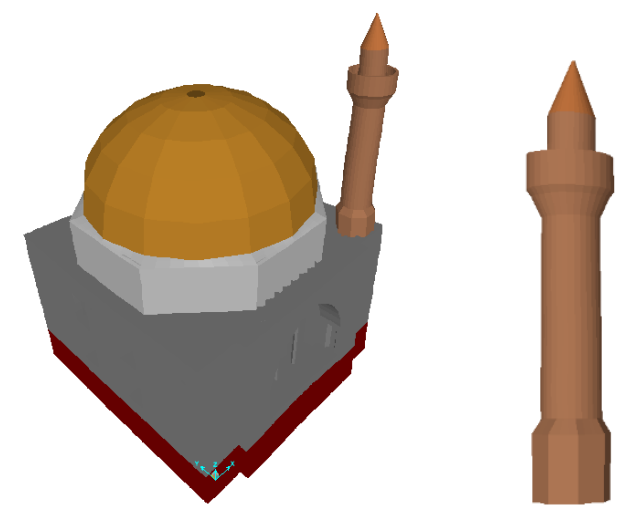

Şekil 15. İlyasbey Camisi ve Minaresi'nin sabit yük etkisindeki yerdeğiştirmesi
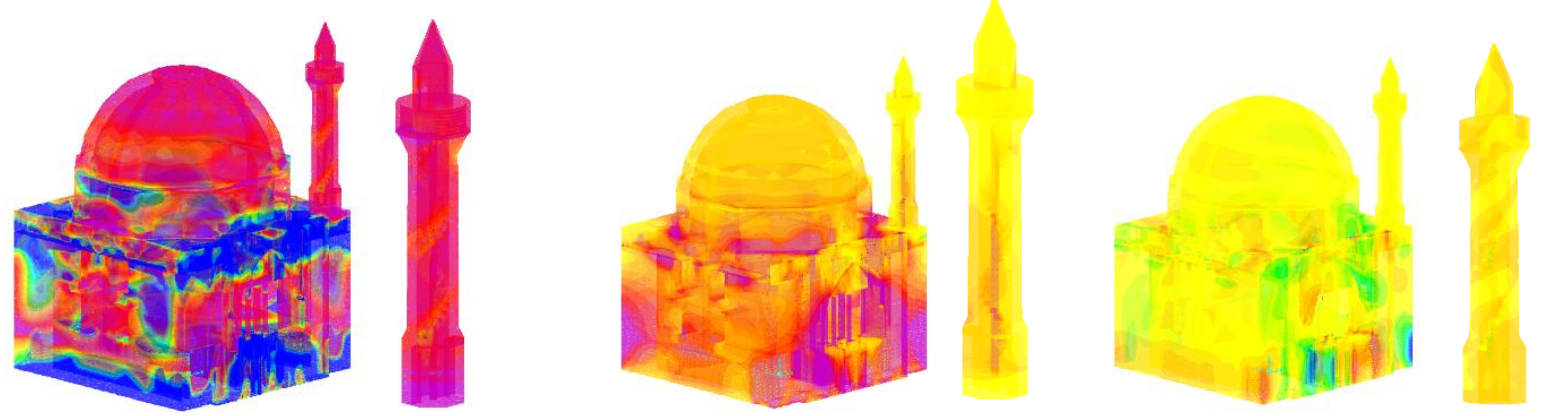

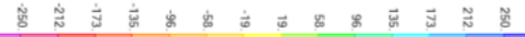

Çekme Gerilmesi Dă̆ılımı

Basınç Gerilmesi Dă̆ılımı

Kayma Gerilmesi Dă̆ılımı

Şekil 16. İlyasbey Camisi ve Minaresi’nin sabit yük etkisindeki gerilme dă̆glımları

Yapıda sabit yük etkisinde oluşan çekme gerilmelerinin caminin kubbesinin orta bölgelerinde, kubbenin mesnetlendiği çemberin üst kısımlarında, gövde duvarlarının orta bölgelerinde ve minare geçiş bölgeleri olan kaide ve şerefeye yakın kısımlarda yoğunlaştı̆̆ 1 belirlenmiştir. Minarede genel olarak çekme gerilmelerinin oldukça düşük olduğu, fakat çekirdekte bazı lokal bölgelerde $0.015 \mathrm{MPa}$ düzeyinde oluştuğu belirlenmiştir. Basınç gerilmelerinin cami duvarının köşe kısımlarında, giriş kapısının kenarlarında, kubbe çemberinin alt kısımlarında ve minarenin çekirdeğinde daha yüksek olduğu belirleniş̧ir. Minare genelinde basınç gerilmelerinin kaide bölgesinde çekirdek kısmında daha fazla olduğu ve lokal olarak $0.120 \mathrm{MPa}$ düzeyinde oluştuğu tespit edilmiştir. Kayma gerilmelerinin ise minare genelinde lokal olarak 0.150MPa düzeyinde olduğu belirlenmiştir. 


\section{B. RÜZGÂR YÜKÜ ETKİSINDEKİ DAVRANIȘIN BELİRLENMESI}

İlyasbey Camisi Minaresi'nin tamamlandığ1 durum için rüzgâr yükü etkisinde gerçekleştirilen analizinden, minarede oluşan yerdeğiştirmeler ile çekme, basınç ve kayma gerilmelerinin dağılımları elde edilmiştir. Minarenin rüzgâr yükü etkisinde yerdeğiştirmiş hali Şekil 17'de, gerilme dağılımları ise Şekil 18 'de verilmektedir. Bu durumda maksimum yerdeğiştirme minarenin tepe noktasında yatay yönde $0.465 \mathrm{~mm}$ olarak meydana gelmiştir.

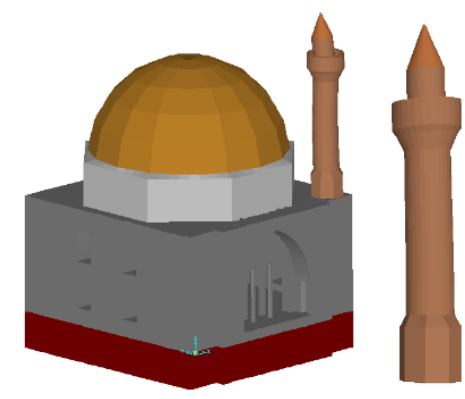

Şekil 17. Illyasbey Camisi Minaresi’nin rüzgâr yükü etkisindeki yerdeğiştirmesi

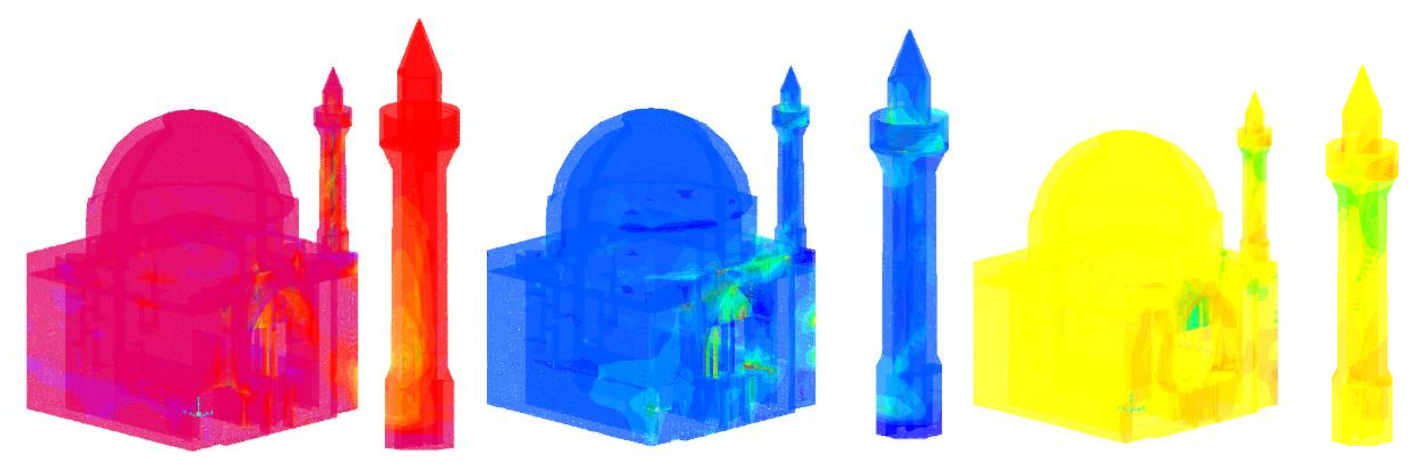

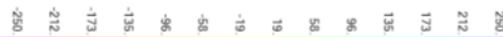

Çekme Gerilmesi Dağılımı

Basınç Gerilmesi Dağılımı

Kayma Gerilmesi Dağılımı

Şekil 18. İlyasbey Camisi Minaresi’nin rüzgâr yükü etkisindeki gerilme dağılımları

Yapıda sabit rüzgar yükü etkisinde oluşan çekme gerilmelerinin caminin minaresinde daha fazla etki oluşturduğu belirlenmiştir. Minarede rüzgâr yükü etkisinde oluşan çekme gerilmelerinin minarenin kaide bölgesinde ve geçiş bölgesinde yoğunlaştığı belirlenmiştir. Çekme gerilmelerinin yapı genelinde 0.015MPa düzeyinde oldukça düşük olduğu, fakat kaide bölgesinde lokal olarak $0.085 \mathrm{MPa}$ düzeyinde olduğu belirlenmiştir. Basınç gerilmelerinin minarenin kaide ve şerefe bölgelerinde yoğunlaştı̆̆ı ve 
0.040MPa düzeyinde oluştuğu tespit edilmiştir. Kayma gerilmelerinin ise minarede oldukça düşük olduğu, fakat lokal olarak 0.015MPa düzeyinde olduğu belirlenmiştir.

\section{MINARENIN DEPREM YÜKÜ ETKISIINDEKİ DAVRANIȘININ BELİRLENMESİ}

İlyasbey Camisi Minaresi'nin Deprem Yer Hareketi Düzeyi-2 (DD-2) durumu için yerdeğiştirmiş hali Şekil 19'da gerilme dağılımları ise Şekil 20'de verilmektedir. Bu durumda maksimum yerdeğiştirme minarenin tepe noktasında yatay yönde $7.850 \mathrm{~mm}$ olarak meydana gelmiştir.

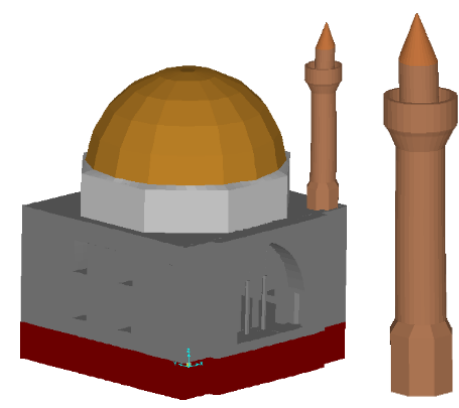

Şekil 19. Illyasbey Camisi Minaresi'nin DD-2 durumu için yerdeğiştirmesi
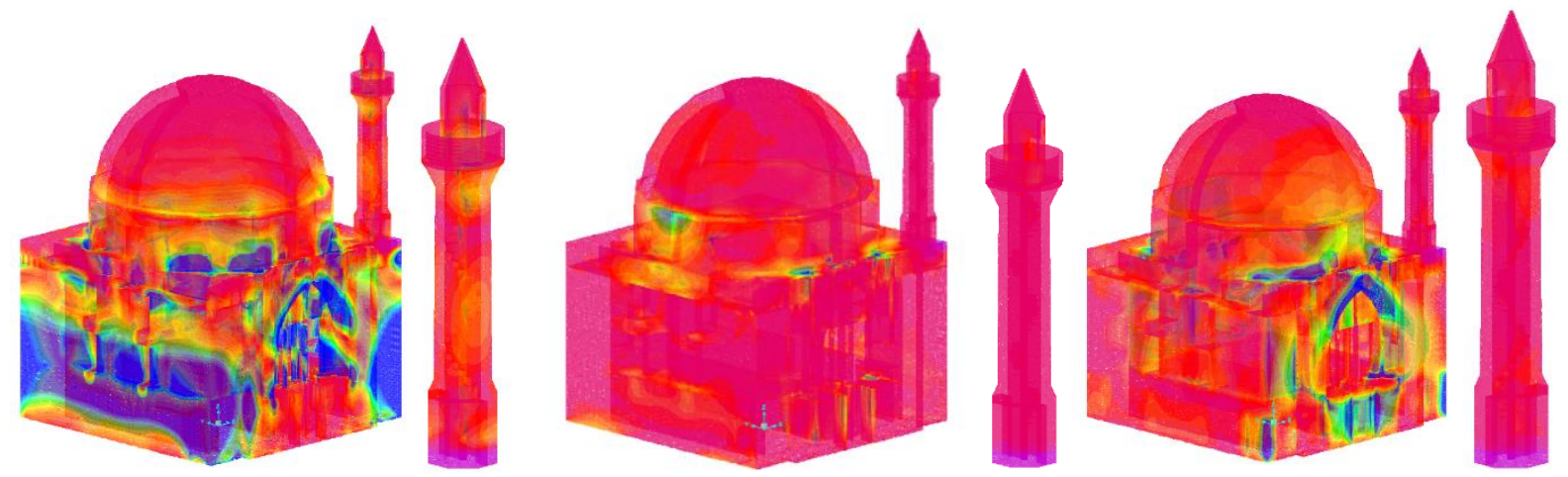

Çekme Gerilmesi Dağılımı

Basınç Gerilmesi Dağılımı

Kayma Gerilmesi Dağılımı

Şekil 20. Illyasbey Camisi Minaresi’nin DD-2 durumu için gerilme dağıllmları

İlyasbey Camisi'nin deprem yükü etkisindeki analizinden çekme gerilmelerinin yapının üst kısımlarında, kubbe ve minarede yoğunlaştığ belirlenmiştir. Minarede DD-2 düzeyi deprem etkisi için oluşan çekme gerilmelerinin şerefe altında lokal olarak 0.250MPa düzeyinde olduğu belirlenmiştir. Basınç gerilmeleri kubbe çemberinin altında yoğunlaştığı tespit edilmiştir. Kayma gerilmelerinin ise 
minare genelinde $0.050 \mathrm{MPa}$ düzeyinde olduğu, fakat lokal olarak $0.080 \mathrm{MPa}$ düzeyinde olduğu belirlenmiştir.

\section{SONUC}

Bu çalışma kapsamında, İlyasbey Camisinin üç boyutlu Sonlu Eleman modeli oluşturulmuş, çevresel titreşim testi ve model kalibrasyonu gerçekleştirilmiştir. Çevresel Titreşim Testi ölçümü, caminin ve minarenin mevcut durumunu yansıtacak şekilde çevresel titreşimler altında Operasyonal Modal Analiz Yöntemi kullanılarak gerçekleştirilmiştir. Başlangıç Sonlu Eleman modeli caminin mevcut durumu yansıtacak şekilde deneysel ölçüm sonuçları dikkate alınarak kalibre edilmiştir. Oluşturulan sonlu eleman modeli üzerinde statik ve dinamik yükler etkisinde lineer analizler gerçekleştirilmiştir. Gerçekleştirilen çalışmadan elde edilen sonuçlar aşağıda maddeler halinde sunulmuştur:

- İlyasbey Camisi'nin çevresel titreşimler altında Operasyonal Modal Analiz Yöntemiyle gerçekleştirilen dinamik ölçümlerinden ilk dört doğal frekansın $7.083-12.96 \mathrm{~Hz}$ arasında değiştiği ve modal sönüm oranlarının \%0.456-1.914 arasında olduğu belirlenmiştir. Mod şekillerinin ise enine ve boyuna öteleme modları ile burulma modları olduğu belirlenmiştir.

- Başlangıç analitik model ile deneysel frekanslar arasında ortalama \%12.06 farklılık meydana gelmiştir. Bu fark, model kalibrasyon işlemiyle ortalama \%3.67'ye kadar azaltılabilmiş̧tir. Bu durumda kalibre edilen analitik modelin mevcut caminin davranışını daha gerçekçi temsil ettiği kabul edilmiştir.

- İlyasbey Camisi Minaresi'nin için analiz sonuçları, sabit yük, rüzgâr yükü ve deprem yükü için incelenmiştir. Minarede oluşan yatay yerdeğiştirmelerin kendi ağırlığı ve rüzgâr etkisinde düşük olduğu, fakat deprem etkisi altında yaklaşık $17 \mathrm{~kat}$ arttığ belirlenmiştir.

- Minarede oluşan basınç gerilmelerin genellikle oldukça düşük olduğu ve 0.040-0.120MPa arasında olduğu belirlenmiştir. Çekme gerilmelerinin ise $0.015-0.250 \mathrm{MPa}$ arasında, kayma gerilmelerinin ise $0.015-0.150 \mathrm{MPa}$ arasında değiştiği belirlenmiştir.

- TBDY (2018) Tablo 11.2'de yığma taşıyıcı duvarların karakteristik basınç dayanımları göre minarenin basınç dayanımı $3.5-5.3 \mathrm{MPa}$ aralığındadır. Çekme dayanımı ise $0.35-0.53 \mathrm{MPa}$ aralığındadır. TBDY (2018)'e göre İlyasbey Cami Minaresinin yapısal analizlerinde elde edilen sonuçlardan, sabit yük, rüzgâr ve DD-2 olan tasarım depreminde oluşacak olan çekme ve basınç gerilmelerinin her bir yükleme için minare duvarlarının taşıyabileceği gerilme değerinden küçük olacağı beklenilmektedir. Buna bağlı olarak bu etkiler altında minarede hasar oluşmaması öngörülmektedir.

\section{KAYNAKLAR}

[1] A. Bayraktar, A. C. Altunışık, T. Türker ve B. Sevim, "Tarihi Köprülerin Deprem Davranışına Sonlu Eleman Model İyileştirmesinin Etkisi”, Altıncı Ulusal Deprem Mühendisliği Konferansı, İstanbul, Ekim, ss. 29-39, 2007.

[2] F. Birinci, "Taş Kemer Köprülerin Sonlu Eleman Modellerinin Operasyonal Modal Analiz Yöntemiyle İyileştirilmesi”, Yüksek Lisans Tezi, Karadeniz Teknik Üniversitesi, Trabzon, Türkiye, 2010.

[3] T. Türker, "Çevresel Titreşim Verileri Kullanılarak Yapıların Hasar Durumlarının Tespiti ve Değerlendirilmesi”, Doktora Tezi, Karadeniz Teknik Üniversitesi, Trabzon, Türkiye, 2011.

[4] C. S. Oliveira, E. Cakti, D. Stenge ve M. Branco, "Deprem Yükü Altındaki Minare Davranışı: Tarihi İstanbul Örneği”. Earthq Eng Struct Dyn, c. 41, ss. 19-39, 2012. 
[5] M. H. Baştürk, "Bursa Tarihi Yığma Minarelerinin Dinamik Davranışlarının Modal Analiz Yöntemiyle İncelenmesi”, Yüksek Lisans Tezi, Uludağ Üniversitesi, Fen Bilimleri Enstitüsü, Bursa, Türkiye, 2013.

[6] E. Ercan ve A. Nuhoğlu, "Üç Açıklıklı Tarihi Yığma Köprünün Yapısal Davranışının Belirlenmesi”, 3. Köprüler Viyadükler Sempozyumu, Bursa, ss. 92-105, May1s, 2015.

[7] T. Türker, A. Bayraktar, İ. Kocaman ve B. Çoruhlu, "Ölçekli Yığma Taş Kemer Köprü Modelinin Dinamik Davranışının Deneysel ve Analitik Olarak İncelenmesi”, 5. Tarihi Eserlerin Güçlendirilmesi ve Geleceğe Güvenle Devredilmesi Sempozyumu, Erzurum, ss. 113-126, Ekim, 2015 .

[8] A. Ural ve F. K. Fırat, "Belirsizlik Altında Kuvvetli Bir Rüzgârla Çöken Duvar Minarelerinin Değerlendirilmesi”, Nat Hazards, c. 76, 2, ss. 999-1018, 2015.

[9] A. Preciado, "Doğrulanmış Sanal Sonlu Eleman Modelleri ile Tarihi Yığma Kulelerinin Simülasyonunda Sismik Güvenlik Açığı ve Başarısızlık Modları”, Eng Fail Anal, c. 57, ss. 72$87,2015$.

[10] M. A. Kömür, Ö. D. İbrahim ve H. R. Yerli, "Düzlem Çelik Çerçeve Sistemlerin Operasyonal Modal Analizi”, Çukurova Üniversitesi Mühendislik Mimarlık Fakültesi Dergisi, c. 30, s. 2, ss. 73-79, 2015.

[11] T. Kocatürk ve Y. S. Erdoğan, "Tarihi Sultan Ahmed Cami M1 Minaresinin Deprem Davranışı”, Struct Eng Mech, c. 59, 3, ss. 539-558, 2016.

[12] R. Livaoğlu, M. H. Baştürk, A. Doğangün ve C. Serhatoğlu, "Geometrik Özelliklerin Tarihi Yığma Minarenin Dinamik Davranışına Etkisi”, KSCE J Civ Eng, c. 20, 6, ss. 2392-2402, 2016.

[13] K. Haciefendioğlu ve E. E. Maraş, "Tarihi Duvar Minarelerinin Belgelerinde ve Ortam Titreşim Testinde Fotogrametri”, Exp Technique, c. 40, 6, ss. 1527-1537, 2016.

[14] İ. Çalık, A. Bayraktar, T. Türker ve A. O. Ayan, "Tarihi Molla Siyah Cami'nin Deneysel Dinamik Davranıșı Üzerine Restorasyon Etkileri”, İnșaat Mühendisliği Sorunları 3. Uluslararası Balkan Konferansı, ss. 362-372, 19-21 May1s 2016.

[15] S. McDonald, "Kablolu Bir Köprünün Operasyonal Modal Analizi, Model Güncellemesi ve Sismik Analizi”, Doctoral dissertation, University of British Columbia, 2016.

[16] İ. Çalık, A. Bayraktar ve T. Türker, "Betonarme Kubbelerin Taş Yığma Duvarlı Camilerin Dinamik Davranışına Etkisinin Çevresel Titreşim Yöntemiyle İncelenmesi”, Journal of the Faculty of Engineering and Architecture of Gazi University, c. 31, ss. 621-630, 2016.

[17] S. Uçak, A. Bayraktar ve T. Türker ve G. Osmancikli, "Operasyonal Modal Analiz Testleri Kullanarak Tarihi Yığma Kubbelerinin Sonlu Elemanlar Modeli Kalibrasyonu”, Journal of Performance of Constructed Facilities, c. 30, 2016.

[18] M. Hejazi, S. M. Moayedian ve M. Daei, "İran Tarihi Tuğla Duvar Minarelerinin Yapısal Analizi", J Perform Constr Facil, c. 30, 2, ss. 1-9, 2016.

[19] İ. Çalık, A. Bayraktar ve T. Türker, "Betonarme Kubbelerin Taş Yığma Duvarlı Camilerin Dinamik Davranışına Etkisinin Çevresel Titreşim Yöntemiyle İncelenmesi”, Journal of the Faculty of Engineering and Architectural of Gazi University, c. 31, ss. 621-630, 2016. 
[20] T. Türker ve A. Bayraktar, "İnşaat Aşamasında Ölçeklendirilmiş Betonarme Binanın Titreşim Esasl1 Modal Testi”, Bulletin of Earthquake Engineering, c. 5, ss. 1-18, 2016.

[21] M. Mirtaheri, A. Abbasi ve N. Salari, "Deneysel ve Sayısal Yöntemlerle Tarihi Yığma Minarenin Deprem Davranış1 ve Rehabilitasyonu", Asian J Civ Eng, c. 18, 5, ss. 807-822, 2017.

[22] G. Bartoli, M. Betti, A. M. Marra ve S. Monchetti, "İnce Yığma Kulelerin Ana Frekansını Tahmin Etmek için Yar1-Deneysel Formülasyonlar”, J Perform Constr Facil, c. 31, 4, ss. 1-10, 2017.

[23] İ. Çalık, A. Bayraktar, T. Türker, E. Hökelekli ve A. O. Ayan, "Trabzon Ortahisar Fatih Camii Restorasyonuna Yönelik Onarım ve Güçlendirme Çalışmaları", 6. Tarihi Yapıların Korunması ve Güçlendirilmesi Sempozyumu, Trabzon, ss. 69-78, 2-4 Kasım 2017.

[24] Y. Yanık, T. Türker, Ö. Yıldırım ve T. Dede, "Yapı Elemanlarının Malzeme Özelliklerinin Model Güncelleme Yöntemiyle Belirlenmesi”, Eurasian Journal of Engineering Sciences and Technology, c. 1, ss. 45-53, 2017.

[25] B. Erdil, M. Tapan, I. Akkaya ve F. Korkut, "Yapısal Parametrelerin Tarihi Yı̆ğma Minarenin Sismik Davranışına Etkisi”, Periodica Polytechnica Civ Eng, c. 62, 1, ss. 148-161, 2018.

[26] A. Bayraktar, İ. Çalık, T. Türker ve A. Ashour, "Yı̆ğma Taş Minarelerinin Deneysel Dinamik Özelliklerine Restorasyon Etkileri”, Materials and Structures, c. 51, 2018.

[27] L. Zhang, R. Brincker ve P. Andersen, "Operasyonal Modal Analize Genel Bir Bakış: Başlıca Gelişme ve Sorunlar”, B\&K Technical Paper, ss. 152-161, 2002.

[28] R. Brincker, C. E. Ventura ve P. Andersen, "Neden Yalnızca Çıktı Modal Testleri, Çok Çeşitli Pratik Uygulamalar İçin İstenilen Bir Araçtır", 21. Uluslararası Modal Analiz Konferansı Bildirisi (IMAC XXI), Kissimmee, Florida, 2003.

[29] J. L. F. S. Ramos, “Titreşim İmzalarına Dayalı Duvar Yapılarında Hasar Tespiti”, Doktora Tezi, Minho Üniversitesi, Portugal, 2007.

[30] N. J. Jacobsen, P. Andersen ve R. Brincker, “ISMA2006'nın Operasyonal Modal Analizinde Harmonik Uyarılmaya Sağlam Bir Teknik Olarak Gelişmiş Frekans Etki Alanı Ayrıștırma Yönteminin Kullanılması", International Conference on Noise and Vibration Engineering, Leuven, Belgium, ss. 3129-3141, 2006.

[31] J. S. Bendat ve A. G. Piersol, Rasgele Veri: Analiz ve Ölçüm Prosedürleri, 3. Baskı, John Wiley and Sons, USA, 2004.

[32] R. Brincker, L. Zhang ve P. Andersen, "Frekans Alanı Ayrışımı Kullanarak Çevre Tepkilerinden Model Belirleme", 18. Uluslararası Modal Analiz Konferansi, San Antonio, USA, ss. 625-630, 2000.

[33] B. Peeters ve G. D. Roeck, "İnşaat Mühendisliğinde Referans Tabanlı Stokastik Alt Alan Tanımlaması", Inverse Problems in Civil Engineering, c. 8, ss. 47-74, 2000.

[34] B. Peeters, "İnşaat Mühendisliğinde Sistem Belirleme ve Hasar Tespiti”, Doktora Tezi, KU Leuven Üniversitesi, Belgium, 2000.

[35] D. J. Yu ve W. X. Ren, "EMD Tabanlı Stokastik Altalanın Operasyonal Titreşim Ölçümlerinden Yap1ların Belirlenmesi”, Engineering Structures, c. 27, ss. 1741-1751, 2005. 
[36] Zemin Etüt Raporu, Aydın İli, Didim İlçesi, Balat Mahallesi, Illyasbey Cami Minaresinin Tamamlanmasina Yönelik Zemin ve Temel Etüt Raporu, Vakıflar Bölge Müdürlüğü, Aydın, 2017.

[37] TBDY, Türkiye Bina Deprem Yönetmeliği, Çevre ve Şehircilik Bakanlığı, Ankara, 2018.

[38] PULSE. (2006), Analizörler ve Çözümler, Release 11.2, Bruel and Kjaer, Sound and Vibration Measurement A/S, Denmark, 2006.

[39] OMA. (2006), Operasyonal Modal Analiz, Release 4.0, Structural Vibration Solution A/S, Denmark.

[40] SAP2000. (2008), Integrated Finite Element Analysis and Design of Structures, Computers and Structures Inc", Berkeley, California, USA.

[41] TS498, Yapı Elemanlarının Boyutlandırılmasında Alınacak Yüklerin Hesap Değerleri, Türk Standartları Enstitüsü, Ankara, 1987.

[42] T. Türker, Illyasbey Camisi Minaresi’nin Yapısal Analizleri, Karadeniz Teknik Üniversitesi, Trabzon, Türkiye, Teknik Rapor, 2017. 